\title{
A review of seismic hazard assessment studies and hazard description in the building codes for Egypt
}

\author{
Rashad Sawires $^{1,2} \cdot$ José A. Peláez $^{2}$ Raafat E. Fat-Helbary ${ }^{3}$. \\ Hamza A. Ibrahim ${ }^{1}$
}

Received: 16 December 2014/Accepted: 23 April 2015/Published online: 8 May 2015

(C) Akadémiai Kiadó 2015

\begin{abstract}
Reduction of damage in earthquake-prone areas requires modern building codes that should be continuously updated to reflect the improvement in our understanding of the physical effects of earthquake ground shaking on buildings and the increase in the quality and amount of seismological and tectonic studies, among other factors. This work reviews the published seismic hazard assessments available for Egypt as well as the seismic actions included in the building codes, in order to show the state-of-the-art of the seismic hazard assessment studies for the country. The review includes the history and development of seismic hazard assessments and the adoption of seismic building codes in Egypt. All the previous studies were analyzed in order to conclude that a new seismic hazard assessment according to the state-of-the-art is desirable, as well as a change in the hazard description for the actual Egyptian building code.
\end{abstract}

Keywords Egypt $\cdot$ Review $\cdot$ Earthquakes $\cdot$ Seismic hazard $\cdot$ Building codes

\section{Introduction}

Of all natural hazards, earthquakes are those which historically have caused the most extensive impact and disruption in terms of damage to infrastructure, human casualties and economic losses. Earthquakes, which happen within few seconds, can destroy people, the whole cities and villages, cultural and material assets created by the people for centuries, as well as changes in the ecological balance of environment. They have the power to trigger landslides, avalanches, flooding and tsunamis. Every year, more than one million

Rashad Sawires

rashad.sawires@gmail.com

1 Department of Geology, Faculty of Science, Assiut University, Assiut, Egypt

2 Department of Physics, University of Jaén, Jaén, Spain

3 Aswan Regional Earthquake Research Center, Aswan, Egypt 
earthquakes shake different regions of the world, some so feeling and gentle that only the most sensitive instruments can detect the motion, and others so violent that whole communities are shattered, and large sections of terrain are shifted in this process that can start landslides, block rivers, cause floods, and set massive sea waves surging across the oceans.

The amount of damage and number of fatalities at a certain location caused by an earthquake, depends on various factors: the magnitude and characteristics of the earthquake focus, distance from the epicenter, soil characteristics, density of buildings and population, and structural design of buildings and infrastructures, among others. These facts are playing an important role in decreasing or increasing the number of victims in recent earthquakes, especially in the developing countries.

Today scientists, technicians and engineers know a lot of details and information about earthquakes, where they are most likely to occur, how deep they originate, and how they affect land. Researchers are applying this knowledge to future programs for predicting when and where the next earthquake might occur and for constructing buildings and installations that should be better able to withstand earthquake violence. Man may never be able to control or even predict earthquakes with satisfactory accuracy, but he can learn to live with them in relative safety. Occurrences of earthquakes in different parts of the world and the resulting losses, especially human lives, have highlighted the structural inadequacy of many buildings to support seismic loads.

It is worth mentioning that the current work doesn't aim at performing seismic hazard analysis in Egypt but rather reviews the main published work regarding this topic. In addition, the seismic actions in the previous and current Egyptian building codes were reviewed and analyzed in relation to the different seismic hazard assessments.

\section{Tectonic setting of Egypt}

Egypt is situating in the northeastern corner of the African Plate, along the southeastern edge of the Eastern Mediterranean region (EMR) (Fig. 1). It is interacting with the Arabian and Eurasian Plates through divergent and convergent plate boundaries, respectively. Egypt is bounded by three active tectonic plate margins: the African-Eurasian plate margin, the Gulf of Suez-Red Sea plate margin, and the Gulf of Aqaba-Dead Sea Transform (DST) Fault. The seismic activity of Egypt is due to the interaction and the relative motion between the plates of Eurasia, Africa and Arabia. Within the last decade, some areas in Egypt have been struck by significant earthquakes causing considerable damage. Such events were interpreted as the result of this interaction.

The primary features of active plate boundaries in the vicinity of Egypt have been discussed in detail by many authors (e.g., McKenzie 1972; Neev 1975; Ben-Avraham et al. 1987; WCC 1985; Meshref 1990; Kebeasy 1990). A summary of the three most important tectonic features in the vicinity of Egypt (Fig. 1), in relation to the known shallow seismicity, is given in the following paragraphs.

\subsection{Africa-Eurasia plate margin}

The African and Eurasian Plates are converging across a wide zone in the Mediterranean Sea (Fig. 1). The effects of the plate interaction are mainly north and remote from the Egyptian coastal margin. Some of the largest events located to the south of Crete and Cyprus islands were felt and caused few damage in the northern part of Egypt (e.g., August 


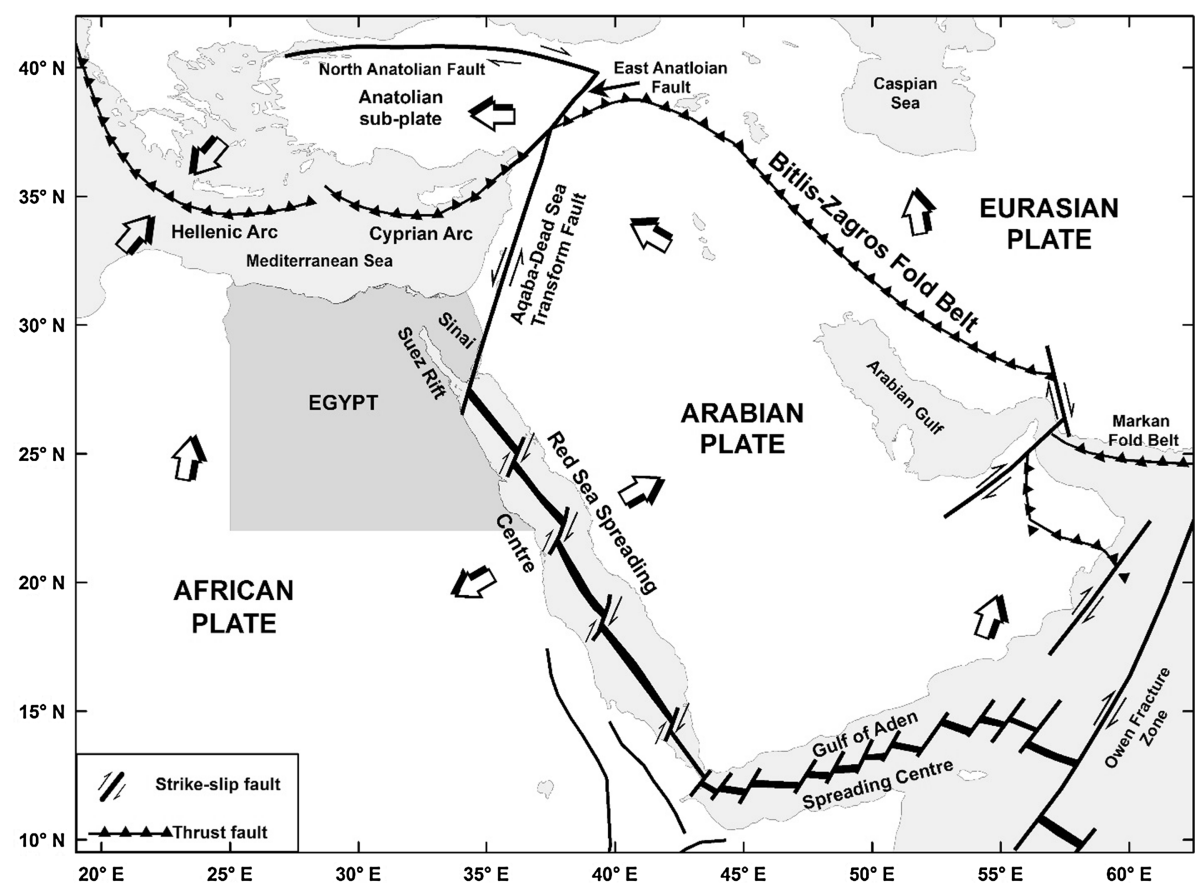

Fig. 1 Global tectonic sketch for Egypt and its vicinity (redrawn after Ziegler 2001 and Pollastro 2003)

8, 1303, intensity VIII offshore Mediterranean, June 26, 1926, $\mathrm{M}_{\mathrm{S}} 7.4$ Hellenic Arc, October 9, 1996, $\mathrm{M}_{\mathrm{W}} 6.8$ Cyprus, and October 12, 2013, $\mathrm{M}_{\mathrm{S}} 6.4$ Crete earthquakes).

\subsection{Gulf of Suez-Red Sea plate margin}

The Arabian Plate is continuing to rotate away from the African Plate along the Red Sea spreading center (Fig. 1). The earthquake activity along this boundary is related to the Red Sea rifting, plutonic activity and the intersection points of the NW (Gulf of Suez-Red Sea Faults) with the NE Gulf of Aqaba-Dead Sea Faults (Abou Elenean 2007). Active sea-floor spreading has been identified as far as about $20^{\circ}$ to $22^{\circ}$ north latitudes (Cochran 1983). The extension of this deformation zone toward the north (Suez-Cairo shear zone) is considered as the most active part of Northern Egypt. The largest earthquakes along this zone caused little damage in Northern Egypt (e.g., March 6, 1900, M 6.2 Gulf of Suez, and March 31, $1969, \mathrm{M}_{\mathrm{W}} 6.8$ Shedwan Island earthquakes).

\subsection{Gulf of Aqaba-Dead Sea Transform}

It is a major left lateral strike-slip fault, trending N-S to NNE-SSW, that accommodates the relative motion between Africa and Arabia (Salamon et al. 2003). It connects a region of extension in the Northern Red Sea with the Taurus collision zone to the north (Fig. 1). The seismic activity of this shear boundary is relatively high and appeared to be clustered in some places where there is an intersection of two or more faults (NNE-SSW and WNW-ESE) or attributed to upwelling of magma (Abou Elenean 2007). Some larger 
earthquake events were reported along this fault trend and caused damage in Northern Egypt (e.g., March 18, 1068, intensity VIII Elat, May 20, 1202, intensity VIII Lebanon, and November 22, 1995, $\mathrm{M}_{\mathrm{S}} 7.2$ Gulf of Aqaba earthquakes).

\section{Seismicity of Egypt}

Egypt has a very long historical record of earthquakes going back four millennia. Moreover, detailed and reliable information is available for several destructive earthquakes in both historical and recent times (Badawy 2005). The seismicity of Egypt (Fig. 2) has been also studied by many authors (e.g., Maamoun et al. 1984; Kebeasy 1990; Ambraseys et al. 1994; Abou Elenean 1997, 2007; Badawy 1999, 2005) as well as the relationship between the surrounding plate boundaries and shallow seismicity (e.g., Abou Elenean 1997).

With the establishment of the Egyptian National Seismic Network (ENSN) in 1997, much activity with more accurate parameters was revealed. The recorded earthquake activity shows a clustering and trending of the activity at specific tectonic structures and faults (Fig. 2). The highest seismicity rates were found at the eastern boundaries of Egypt, via the Gulf of Aqaba, which forms the southern end of the DST fault, and the northern part of the Red Sea, which is a young oceanic spreading center (Abou Elenean 2007).

However, significant seismic activity is also found along the entire Gulf of Suez and its extension on the northern part of the Egyptian Eastern Desert towards the Nile Delta along the E-W and WNW faults. This activity trend does not continue further towards the Mediterranean Sea and ceased closer to the west of the Nile Valley. The activity along the Northern Red Sea lies along the axial part of the rift. Furthermore, some clusters around supposed transform faults were clearly observed (Abou Elenean 2007). Away from this relatively active seismic zone, inland seismic activity (e.g. in Dahshour, Aswan, AbuDabbab and Abu-Simbel) has also occurred (Badawy 2005).

Badawy (2005) mentioned that, with the improvement of the ENSN, new seismically active zones have been discovered across and around Egypt (e.g., Southeast Beni Suef, west of Sohag, and along what used to be considered a seismic gap between the Southern Red Sea and Northernmost Red Sea). More recently, Abou Elenean (2007) described two seismicity clusters which were located in the southern part of the Western Desert (Southwest Aswan and Northeast Abu Simbel) (Fig. 2). He attributed these activities to some tectonically E-W active faults and reservoir-induced seismicity around Nasser's Lake. In addition, he identified some clusters along the Nile River, trending NW-SE to WNW-ESE, which were observed along the Nile Valley to the north of Idfu, west of Assiut and Southwest Beni Suef (Fig. 2).

\section{Earthquake risk}

Egypt is affected by moderate seismic activity compared to other countries, nevertheless it is exposed to a relatively high seismic risk. This is due to number of factors: (a) the population in Egypt, as well as all important and archaeological sites, are concentrated within a narrow belt along the Nile Valley and Delta, (b) most of the moderate and significant earthquakes occurred near densely-populated cities and villages, (c) the methods of construction vary between old and new buildings with poor construction practice, and finally, (d) the soil characteristics in different localities in Egypt have a clear influence 


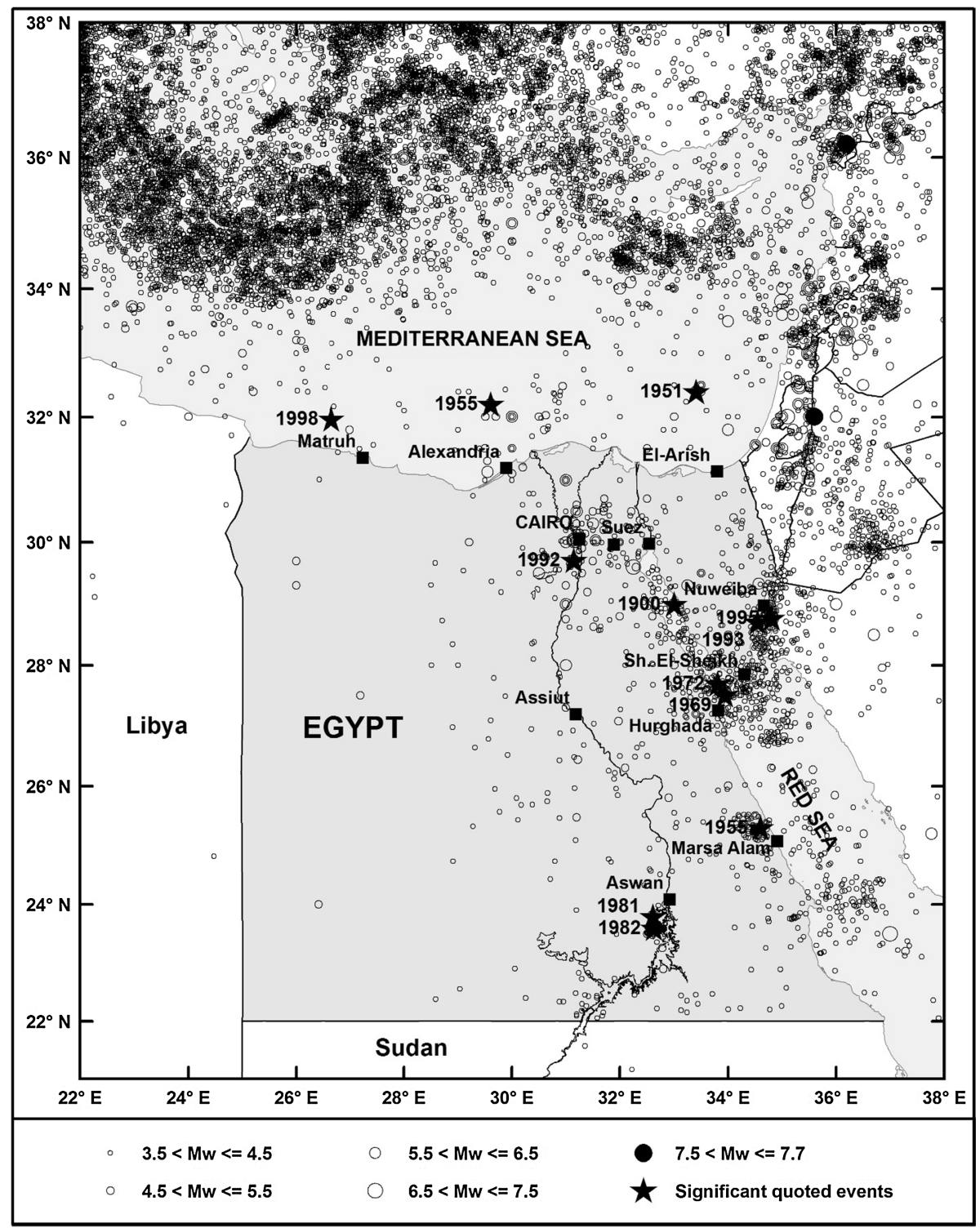

Fig. 2 Declustered shallow seismicity and significant earthquakes (see text) for the time period (2200 B. C.-2013) (after Sawires et al. 2014, 2015)

on seismic waves amplification. A damaging earthquake is a real, as well as a current, threat to the safety, social integrity, and economic well-being of the population in the region.

Earthquake damages in Egypt are generally related to the occurrence of moderate-size earthquakes at short distances (e.g., 1992, $\mathrm{M}_{\mathrm{S}} 5.9$ Cairo earthquake), rather than bigger earthquakes that are known to occur at far distances along the Northern Red Sea, Gulf of 
Table 1 Instrumental earthquakes above $M_{W} 5.5$ that affected Egypt since 1900 (after Sawires et al. 2014)

\begin{tabular}{lllllll}
\hline $\begin{array}{l}\text { Date } \\
(\text { yyyymmdd })\end{array}$ & $\begin{array}{l}\text { Time } \\
(\mathrm{hhmmss})\end{array}$ & $\begin{array}{l}\text { Longitude } \\
\left({ }^{\circ} \mathrm{E}\right)\end{array}$ & $\begin{array}{l}\text { Latitude } \\
\left({ }^{\circ} \mathrm{N}\right)\end{array}$ & $\begin{array}{l}\text { Depth } \\
(\mathrm{km})\end{array}$ & $\begin{array}{l}\text { Moment } \\
\text { magnitude }\end{array}$ & Epicentral region \\
\hline 19000306 & 175800 & 33.000 & 29.000 & - & 6.2 & Gulf of Suez \\
19510130 & 230723 & 33.410 & 32.400 & 30 & 5.7 & Offshore Sinai Peninsula \\
19550912 & 060924 & 29.610 & 32.200 & 20 & 6.4 & Offshore Alexandria \\
19551112 & 053214 & 34.600 & 25.300 & 33 & 5.5 & Abu Dabbab, Eastern Desert \\
19690331 & 071551 & 33.938 & 27.513 & 06 & 6.8 & Shedwan Island, Red Sea \\
19720628 & 094935 & 33.810 & 27.700 & 07 & 5.5 & Shedwan Island, Red Sea \\
19811114 & 090523 & 32.610 & 23.800 & 19 & 5.8 & Aswan, Southern Egypt \\
19820423 & 144257 & 32.629 & 23.598 & 11 & 5.5 & Aswan, Southern Egypt \\
19921012 & 130957 & 31.142 & 29.712 & 22 & 5.8 & Dahshour, Southwest Cairo \\
19930803 & 124308 & 34.548 & 28.708 & 18 & 6.1 & Gulf of Aqaba \\
19951122 & 041515 & 34.809 & 28.769 & 19 & 7.2 & Gulf of Aqaba \\
19980528 & 183332 & 26.650 & 31.970 & 10 & 5.5 & Offshore, Ras El-Hikma \\
\hline
\end{tabular}

Suez, and Gulf of Aqaba (e.g., 1969, $\mathrm{M}_{\mathrm{S}}$ 6.9 Shedwan, and 1995, $\mathrm{M}_{\mathrm{W}} 7.2$ Gulf of Aqaba earthquakes), as well as the Mediterranean offshore (e.g., 1955, $\mathrm{M}_{\mathrm{S}} 6.8$ Alexandria earthquake) (Abou Elenean et al. 2010). Although the 1995, $\mathrm{M}_{\mathrm{W}} 7.2$ Gulf of Aqaba earthquake was the strongest one, it was the 1992, $\mathrm{M}_{\mathrm{S}} 5.9$ Cairo event that left the deepest imprints on everyone, not only because it resulted in hundreds killed and injured people, but also because it incurred a huge economic loss in damages, making it one of the costliest natural disasters in Egypt. The most significant local earthquakes $\left(\mathrm{M}_{\mathrm{W}} \geq 5.5\right)$ which have been located in Egypt since the year 1900 until the end of 2013, were listed in Table 1 and depicted in Fig. 2. Among those earthquakes, some details about the most terrifying and damaging events were described in the following.

- March 6, 1900 Gulf of Suez earthquake $\left(M_{S}\right.$ 6.2, $M_{W}$ 6.2). It was located in an unpopulated area in the Gulf of Suez between Zafarana and Gharib to the west of the gulf, and Maghara, in Sinai (Fig. 2). It caused rock falls. In Cairo, the earthquake consisted of three consecutive shocks lasting in all about $30 \mathrm{~s}$. They were felt by everyone and some people gone out from their houses.

- September 12, 1955 offshore Alexandria earthquake $\left(M_{S} 6.8, M_{W} 6.4\right)$. This earthquake was felt in the entire Eastern Mediterranean Basin (Fig. 2). In Egypt, it was felt strongly, and led to the loss of 22 lives and damage in the Nile Delta between Alexandria and Cairo. Destruction of more than 300 buildings of old brick construction was reported. A maximum intensity of VII was assigned to a limited area in the Bihira province, where five people died and 41 were injured. In addition, intensities between $\mathrm{V}$ and VII were reported in 15 other localities (Kebeasy 1990).

- November 12, 1955 Abu-Dabbab (Eastern Desert) earthquake ( $\left.M_{S} 5.3, M_{W} 5.5\right)$. This event was felt in Upper Egypt in Aswan, Qena and as far as Cairo, but no damage was reported.

- March 31, 1969 Shedwan Island earthquake ( $\left.M_{S} 6.9, M_{W} 6.8\right)$. This event occurred to the northwest of Shedwan Island, in the surroundings of the Gulf of Suez (Fig. 2). On the island, fissures and cracks in the soil were found. Ten kilometers to the west from the fractured area in the sea, a submerged coral reef was raised above sea level after the event. This event was also felt in Saudi Arabia (Kebeasy 1990; El-Sayed et al. 1994). 
- November 14, 1981 Aswan (Kalabsha) earthquake ( $m_{b}$ 5.3, $M_{S}$ 5.6, $M_{W}$ 5.8). This earthquake occurred in the Nubian Desert of Aswan (Fig. 2). It is of great significance because of its possible association with Nasser's Lake. Its effects were strongly felt to the north of its epicenter (Kalabsha) up to Assiut, and to the south up to Khartoum. The epicentral intensity was VII-VIII. Surface faulting was reported in the epicentral area. Several cracks on the western bank of the Nasser's Lake, and several rock-falls and minor cracks on the eastern bank were reported. This event caused a great alarm due to its proximity to the Aswan High Dam (Kebeasy 1990, El-Sayed et al. 1994).

- October 12, 1992 Cairo (Dahshour) earthquake ( $\left.m_{b} 5.8, M_{S} 5.9, M_{W} 5.8\right)$. It produced a disproportional amount of damage (estimated at more than 500 million of Egyptian pounds) and the loss of many lives. The shock was strongly felt and caused occasional damage and life loss in the Nile Delta, around Zagazig (Fig. 2). The mostly affected area was Cairo, Bulaq and the region to the south, along the western bank of the Nile to Gerza (Jirza) and El-Rouda. In all, 350 buildings collapsed completely and 9000 were irreparably damaged, 545 people died and 6512 people were injured. About 350 schools and 216 mosques were ruined, and about 50,000 people were left homeless. It is considered one of the most significant earthquakes in Egypt during the last century (El-Sayed et al. 1994; Abou Elenean et al. 2000).

- November 22, 1995 Gulf of Aqaba earthquake ( $M_{W}$ 7.2). It was a strong earthquake located in the southern part of the Gulf of Aqaba (Fig. 2). Most of the reported damage was concentrated in the Sinai Peninsula, leading to loss of three lives. Damage was also reported in the platforms of the port facilities in Nuweiba (Abdel-Fattah et al. 2006).

- May 28, 1998 Ras El-Hikma earthquake $\left(m_{b}\right.$ 5.5, $M_{W}$ 5.5). It was located offshore, on the northwestern part of Egypt, and it was widely felt in Northern Egypt (Fig. 2). The maximum intensity of VII was assigned at Ras El- Hikma village $(\sim 300 \mathrm{~km}$ west of Alexandria), and an intensity equal to V-VI at Alexandria. Ground fissures were observed along the beach, and also some cracks in the concrete buildings (Hassoup and Tealab 2000).

\section{Seismic hazard assessments studies}

In the last decades, some seismic hazard assessments for the whole territory of Egypt and several studies for specific localities (e.g., Aswan and Sinai) have been done (Tables 2, 3). Early assessments were done by Kebeasy et al. (1981), Albert (1986, 1987), Sobaih et al. (1992), El-Sayed et al. (1994), Fat-Helbary and Ohta (1996), and Badawy (1998). Some of these studies evaluated the earthquake hazard regardless of seismic source zones, and others estimated the seismic hazard upon the delineation of seismic sources depending on the major tectonic trends prevailing in Egypt. Recently, several seismic hazard studies were carried out for both specific regions and the whole territory of Egypt. Among these studies are the following: Riad et al. (2000), El-Sayed et al. (2001), Fat-Helbary (2003), ElHefnawy et al. (2006), Deif et al. (2009, 2011), Hamouda (2011a, b), and Mohamed et al. (2012).

Among these studies, the study carried out by Riad et al. (2000) computed the peak ground acceleration (PGA) values that were considered in the Egyptian building codes for the years 2004, 2008 and 2011, and also in the Global Seismic Hazard Assessment Project (GSHAP 1999). 


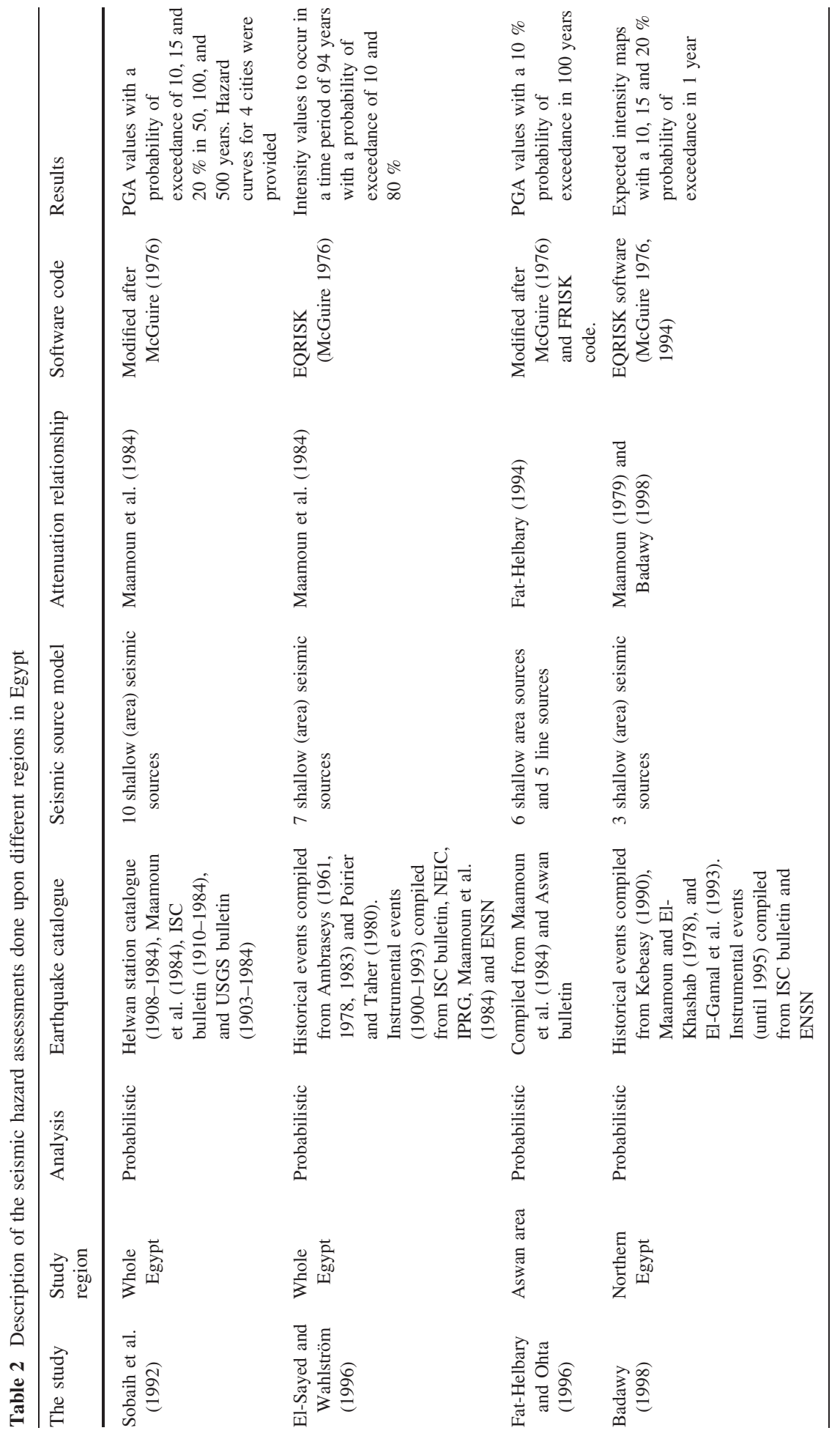




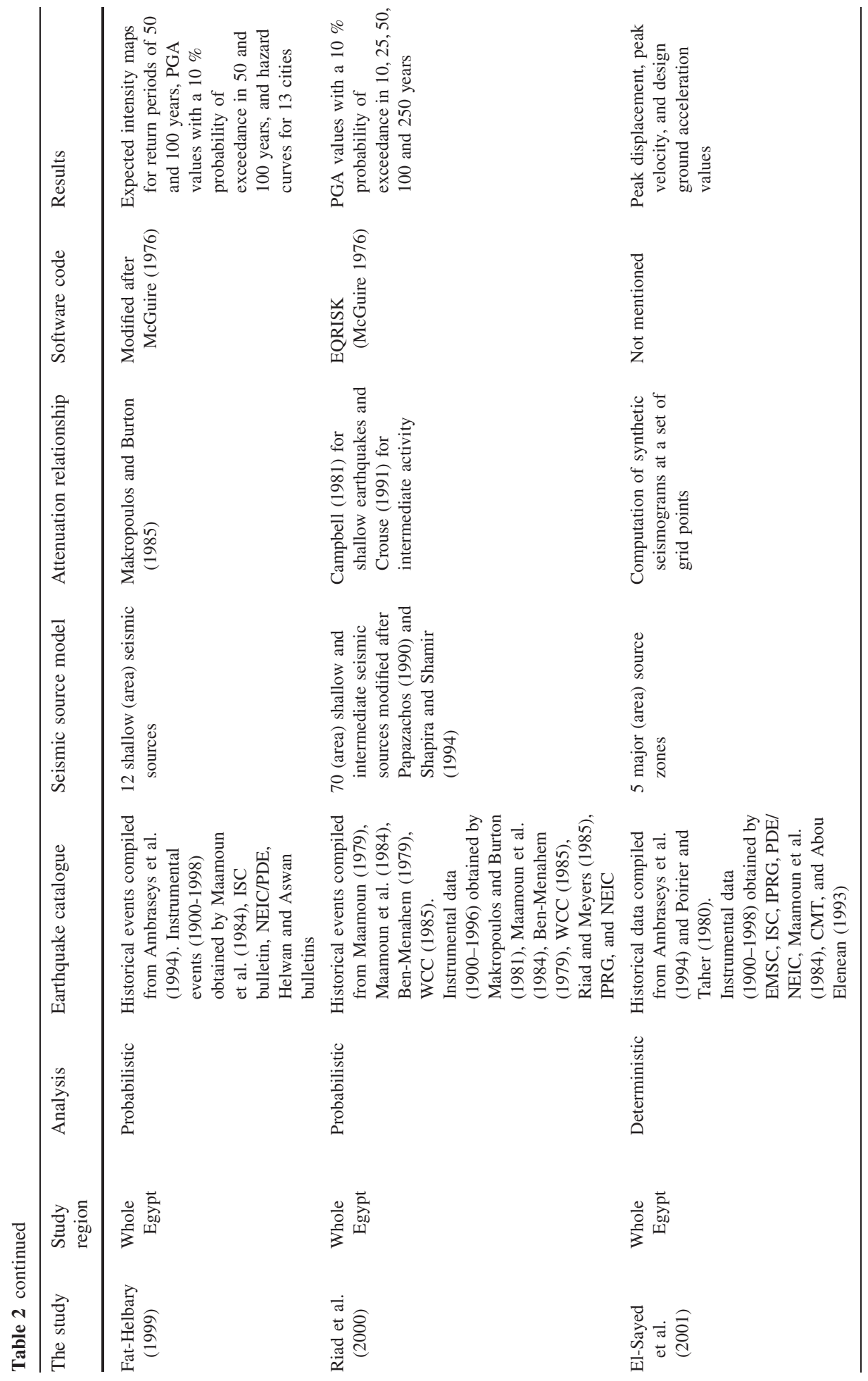




\begin{tabular}{|c|c|c|c|c|c|}
\hline 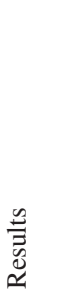 & 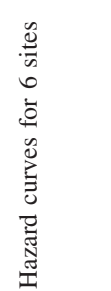 & 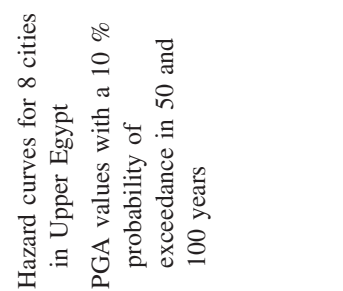 & 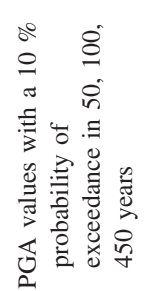 & 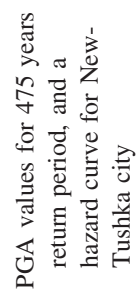 & 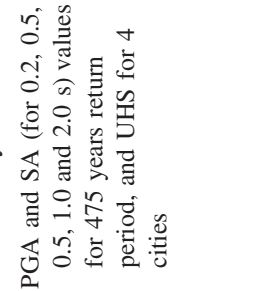 \\
\hline 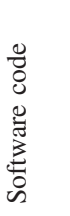 & 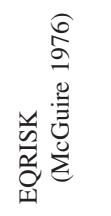 & 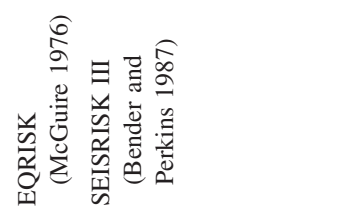 & 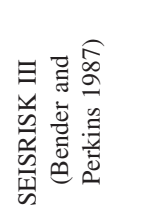 & 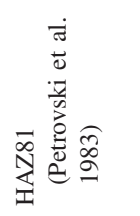 & 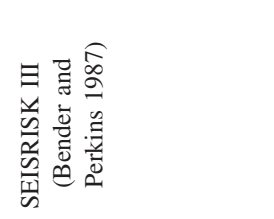 \\
\hline 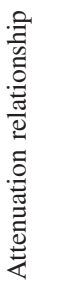 & 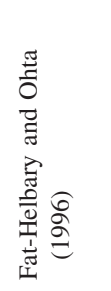 & 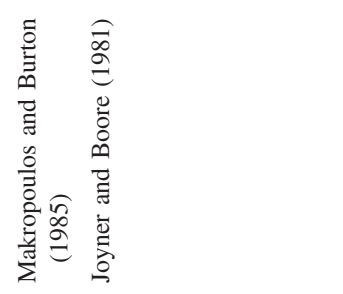 & 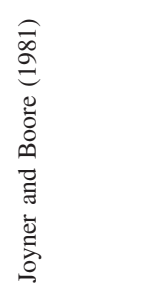 & 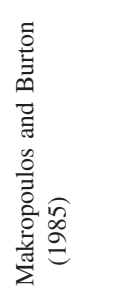 & 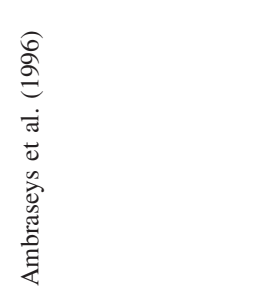 \\
\hline 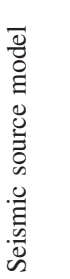 & 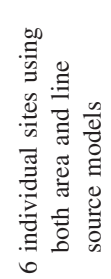 & 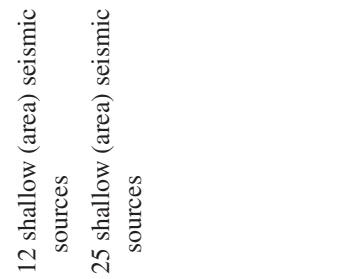 & 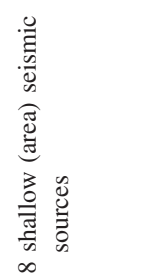 & 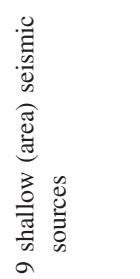 & 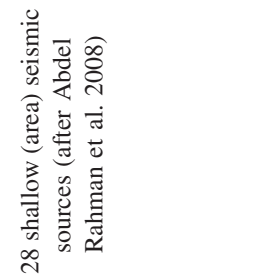 \\
\hline 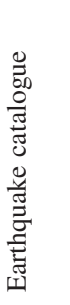 & 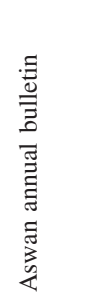 & 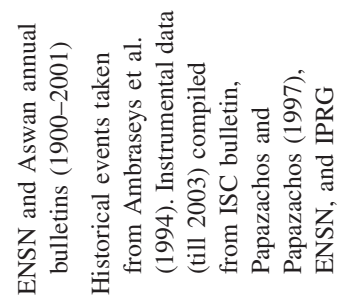 & 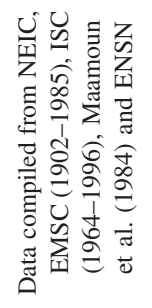 & 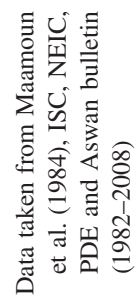 & 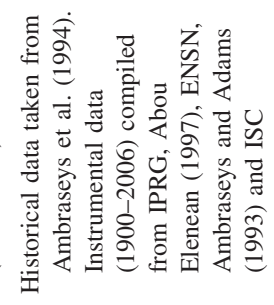 \\
\hline & 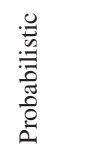 & 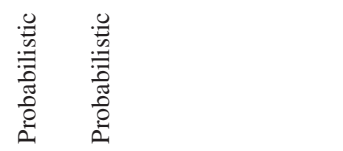 & 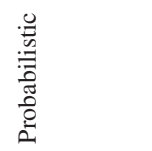 & 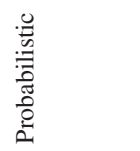 & 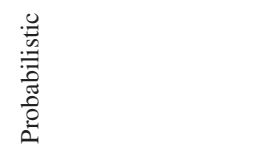 \\
\hline 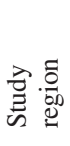 & 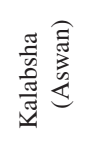 & 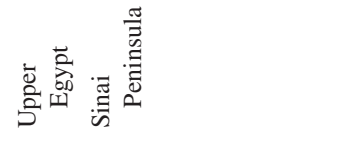 & 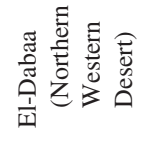 & 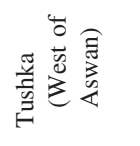 & 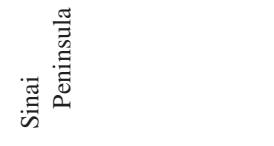 \\
\hline 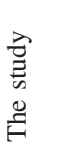 & 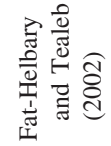 & 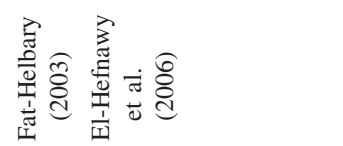 & 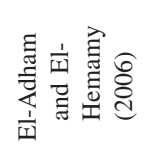 & 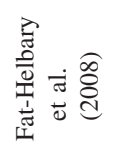 & 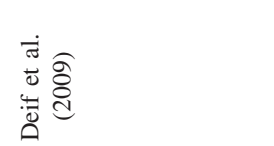 \\
\hline
\end{tabular}




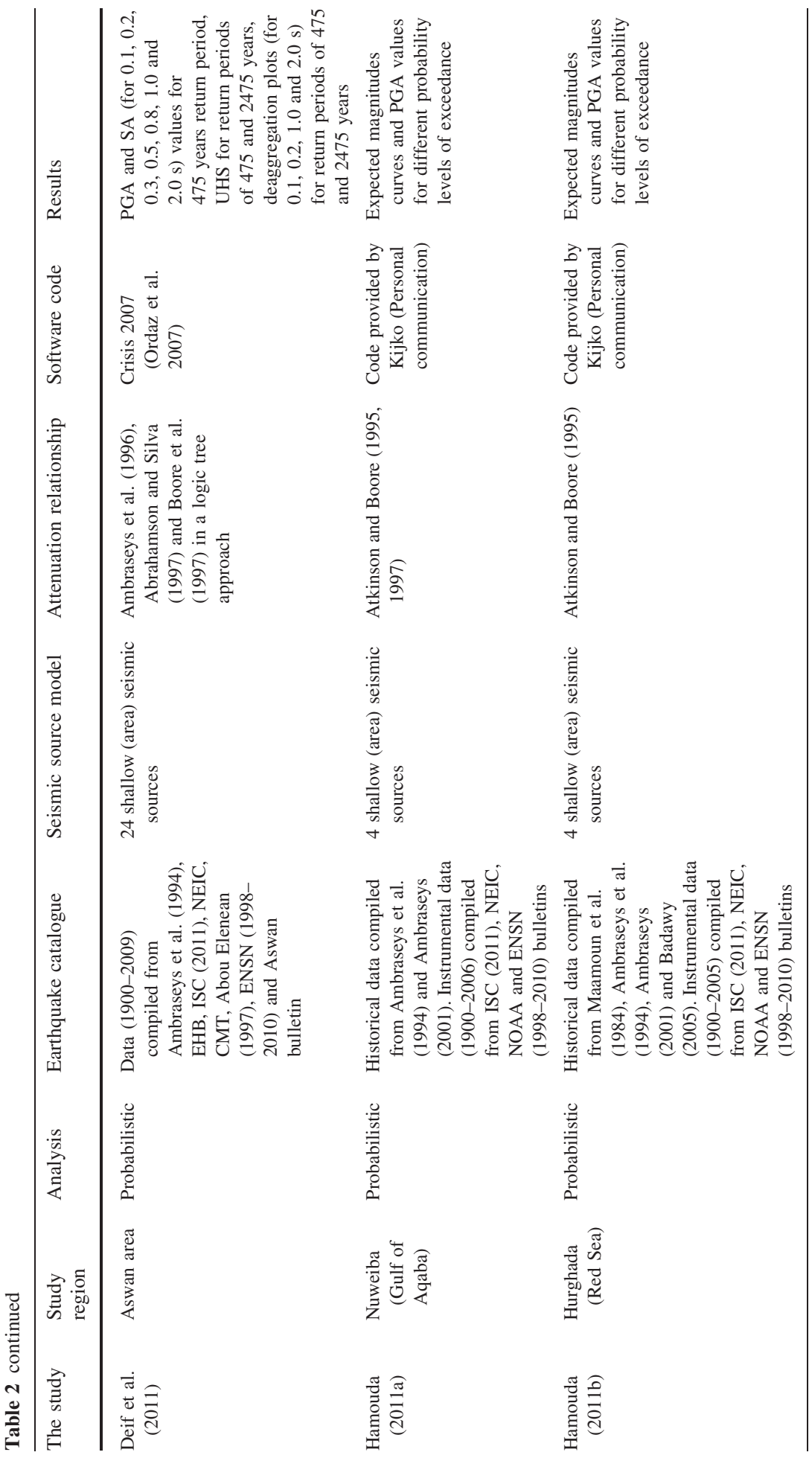




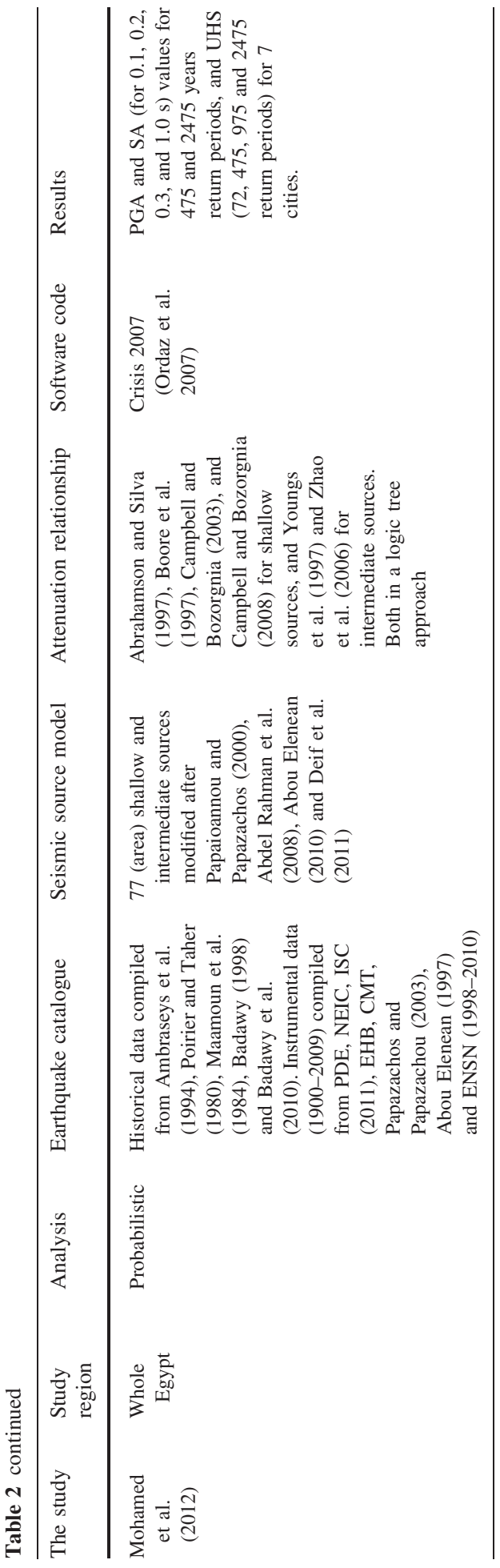

글 Springer 
Table 3 Computed PGA values (g) with a $10 \%$ probability of being exceeded in 50 years (475 years return period) for some selected cities in Egypt

\begin{tabular}{lllllll}
\hline Study & Cairo & Alexandria & Suez & Assiut & Hurghada & Aswan \\
\hline Fat-Helbary (1999) & 0.15 & $0.07-0.10$ & 0.17 & $0.05-0.07$ & 0.17 & 0.25 \\
Riad et al. (2000) & 0.13 & $0.10-0.13$ & 0.13 & $0.08-0.10$ & $0.20-0.23$ & $0.10-0.13$ \\
Fat-Helbary (2003) & - & - & - & 0.05 & 0.21 & 0.26 \\
El-Hefnawy et al. (2006) & - & - & 0.05 & - & $0.09-0.10$ & - \\
Fat-Helbary et al. (2008) & - & - & - & $0.05-0.06$ & $0.14-0.15$ & $0.11-0.14$ \\
Deif et al. (2009) & - & - & $0.06-0.08$ & - & $0.06-0.08$ & - \\
Deif et al. (2011) & - & - & - & - & - & 0.07 \\
Mohamed et al. (2012) & 0.10 & 0.05 & 0.10 & 0.05 & 0.13 & $0.07-0.10$ \\
\hline
\end{tabular}

The GSHAP was launched in 1992 by the International Lithosphere Program (ILP) with the support of the International Council of Scientific Unions (ICSU), and was endorsed as a demonstration program in the framework of the United Nations International Decade for Natural Disaster Reduction (UN/IDNDR). This project was finished in 1999. The primary goal of GSHAP was to create a seismic hazard map in a harmonized and regionally coordinated fashion, using a probabilistic seismic hazard assessment (PSHA). As a result of this project, a worldwide and four regional seismic hazard maps were created through a compilation of independent studies conducted for various parts of the globe. Egypt is included in the map for Europe, Africa and the Middle East (GSHAP 1999). The probabilistic ground shaking map for the EMR was assembled at ETH Zurich, on the basis of contributions of different authors (for Egypt, S. Riad, E. Ibrahim and M. Sobaih). The resulting regional map is not a computed map, but rather a smoothed composite map based on the existing ground shaking hazard maps of individual EMR countries (GSHAP 1999). All maps were computed for PGA values corresponding to a $10 \%$ probability of exceedance in 50 years.

Tables 2 and 3 describe, in some details, the main differences between the available mentioned seismic hazard assessments which carried out upon Egypt. Table 2 gives information, for each study, about the studied area, the approach used in the analysis, the spatial and temporal spanning of the used earthquake catalogue, the seismic source model, the considered attenuation relationship, the software code, and a brief description about the results obtained from each study. It is clear that the majority of these seismic hazard studies are preferred to use the probabilistic than the deterministic approach in their assessments. Both the probabilistic and deterministic approaches have an important role in the seismic hazard assessments. The two approaches have differences, advantages and disadvantages, which in turn can complement each other. The analyzer would prefer one approach over the other depending on several factors: (a) how quantitative are the decisions to be made, (b) the seismic environment, and finally (c) the main scope of the project.

On the other hand, Table 3 compares the PGA values (for a return period of 475 years) for the available studies, for some of the most populated and important cities in Egypt. The observed differences might be attributed to several reasons; (a) the use of different seismic hazard approaches, (b) the consideration of distinct earthquake catalogues spanning different time periods, (c) the considered seismic source model, or (d) the used ground motion attenuation model. 
Below, we are describing in details two of the most significant studies carried out until now. The first study was performed by Riad et al. (2000) which, as mentioned before, is the work considered in the Egyptian building codes (ECP-201 2004, 2008, 2011). The other one, is the most recent study until now, performed by El-Hadidy (2012) and published by Mohamed et al. (2012), which includes the most updated earthquake data.

\subsection{Riad et al. (2000) study}

This work included the following steps: compilation and creation of a database for seismic events spanning the time period (2800 B.C.-1996), definition of a seismic source model, and a probabilistic study based on an area source model. As a result, different PGA maps were obtained for all the Egyptian territory, for a probability of exceedance of $10 \%$ in 10 , 25, 50, 100 and 250 years. An explanation of the different aspects considered in the development of this study follows.

\subsubsection{Earthquake catalogue}

A modified and updated earthquake catalogue for Egypt and surrounding areas affecting Egypt was prepared. The earthquake data were compiled from the following catalogues. For the period 2800 B.C.-1899: Maamoun (1979), Ben-Menahem (1979), Maamoun et al. (1984), and WCC (1985). For the period 1900-1996: Ben-Menahem (1979), Makropoulos and Burton (1981), Maamoun et al. (1984), WCC (1985), Riad and Meyers (1985), Shapira (1994), and NEIC (1995, 1996).

\subsubsection{Seismic source model}

The delineation of the seismic source zones developed in this study was mainly based on the generally accepted concepts of the regional tectonics, available geological maps and the seismicity. In this respect, observed seismic activity at or near a main fault, or in a faulted area, was a dominant parameter in identifying seismic source zones. The authors defined 56 seismic source zones of "shallow" (h $\leq 70 \mathrm{~km}$ ) seismic activity and six zones of "intermediate" ( $\mathrm{h} \geq 70 \mathrm{~km}$ ) seismic activity. The regional delineation consisted of five basic trends: the Greek trend, based on the seismic zone regionalization of Papazachos (1990), the Dead Sea trend, which was mainly based on the earthquake catalogue of Israel and its vicinity after Shapira and Shamir (1994), the Pelusium and Qattara trends, the Eastern Mediterranean trend, and the Aswan area.

\subsubsection{Ground motion attenuation equations}

Since Egypt did not have an adequate strong-motion network, there isn't an attenuation relationship developed specifically for the country. Therefore, attenuation relationships developed for other regions were used. Furthermore, most active regions surrounding Egypt are of shallow seismicity associated with surface ruptures, thus the authors used the regional attenuation relationship of Campbell (1981) for central United States. In addition, they applied the attenuation model of Crouse (1991) for the subduction zones of Greece. 


\subsubsection{Approach, software code and results}

A PSHA procedure was followed in this work (using EQRISK software code developed by McGuire, 1976). Iso-acceleration contour maps were computed, with a $90 \%$ probability of non-exceedance for exposure times of 10, 25, 50, 100 and 250 years. PGA values with a $90 \%$ probability of not being exceeded in 50 years (475 years return period) will be shown in Sect. 6.4. In this study, the authors obtained the highest PGA levels at the Southern Gulf of Suez (range of 110-220 cm/s ${ }^{2}$ ). In addition, the populated areas of Egypt (e.g., the Nile Delta, Cairo and Fayoum) are threatened by PGA values of the order of $110 \mathrm{~cm} / \mathrm{s}^{2}$. Furthermore, they obtained seismic hazard values along the northern coast of Egypt of about $100 \mathrm{~cm} / \mathrm{s}^{2}$.

\subsection{El-Hadidy (2012) and Mohamed et al. (2012) studies}

As part of the doctoral work of El-Hadidy (2012), a recent evaluation of the seismic hazard for all the Egyptian territory was carried out. This work included the following steps: compilation of an earthquake database for the time period 112 B.C.-2011, consideration of a new seismic source model, and a probabilistic study within a logic-tree framework. As a result, PGA and spectral acceleration (SA) values, and unified hazard spectra (UHS) for different locations were obtained. The seismic hazard values for rock were calculated for four spectral periods $(0.1,0.2,0.3$ and $1 \mathrm{~s})$ and for four different return periods $(72,475$, 950 and 2475 years). A brief explanation of the different aspects considered in the development of this study follows.

\subsubsection{Earthquake catalogue}

An updated earthquake catalogue for Egypt and surrounding areas was used in this study. The historical seismicity data of Egypt (112 B.C.-1899) was compiled from Maamoun et al. (1984), Poirier and Taher (1980), Ambraseys et al. (1994), Badawy (1998), Riad et al. (2000), and Badawy et al. (2010), while the instrumental data (1900-2011) were collected from the PDE bulletin, ISC bulletin, EHB (Engdahl et al. 1998) catalogue, CMT catalogue, Maamoun et al. (1984), Ambraseys et al. (1994), Papazachos and Papazachou (2003), Abou Elenean (1997), and the annual bulletin of the ENSN.

\subsubsection{Seismic source model}

Two alternative seismic source models were used in this work, which characterize earthquakes in three tectonic environments: subduction zones (Cyprian and Hellenic Arcs), strikeslip environments (Gulf of Aqaba-Dead Sea Transform), and normal faults (Red Sea-Gulf of Suez-Cairo trend), as well as five background seismicity zones. The first one is the model proposed by Abou Elenean (2010). The authors established a detailed zonation map for whole Egypt and its surroundings, considering the recent seismicity distribution and focal mechanism data. Forty one seismic source zones of "shallow" earthquakes $(\mathrm{h} \leq 60 \mathrm{~km})$ in and around Egypt were considered. In addition, seven seismic sources were considered for "intermediate-depth" (60 $\leq \mathrm{h} \leq 200 \mathrm{~km})$ events within the Hellenic Arc (after Papazachos and Papaioannou 1993). The second used model, which consisting of 72 sources, is the one proposed by El-Hadidy (2012). He compiled and integrated a new seismic zoning map for 
Egypt and its surroundings, which was mainly based on seismic sources from previous studies (Abdel Rahman et al. 2008; Deif et al. 2011; Papaioannou and Papazachos 2000).

\subsubsection{Ground motion attenuation equations}

The authors of this study applied the ground-motion models of Youngs et al. (1997), and Zhao et al. (2006) for subduction seismic sources, and the models of Abrahamson and Silva (1997), Boore et al. (1997), Campbell and Bozorgnia (2003), and Campbell and Bozorgnia (2008), in a logic-tree framework, for shallow seismic zones.

\subsubsection{Approach, software code and results}

El-Hadidy (2012) and Mohamed et al. (2012) follow in their assessments a probabilistic approach. The seismic hazard analysis was performed using the CRISIS (2007) software code (Ordaz et al. 2007). This study led to the generation of a number of seismic hazard maps at rock sites for different return periods and spectral accelerations. They obtained the highest PGA values close to the Gulf of Aqaba $\left(220 \mathrm{~cm} / \mathrm{s}^{2}\right.$ for a return period of 475 years) (Fig. 3). In addition, UHS for rock sites for seven cities (Cairo, Alexandria, Aswan, Assiut, Sharm El-Sheikh, El-Arish and Matruh) were specifically computed.

From Table 3, an overall decrease in the hazard values in the second study by ElHadidy (2012) and Mohamed et al. (2012) was observed, with the exception of the Gulf of Aqaba region (Fig. 3). In addition, a significant difference in the PGA values for the different cities was observed among these two studies. As mentioned before, these differences are clearly related to the distinct input parameters into both analyses. The authors in the second assessment used a combination of ground motion attenuation models in a logic tree approach, which gives different ground motion values than those used in the study conducted by Riad et al. (2000). Moreover, authors used a different seismic source model with different seismicity parameters.

\section{Seismic design codes}

The first version of the Egyptian Concrete Code started in 1930, then was updated in 1962, 1969 and 1988. Before 1989, consideration of seismic input was absent from national codes in Egypt. Buildings were typically designed to resist gravity loads, and the only means of lateral load resistance was provided through the consideration of wind loads in some cases. The first official code of practice to consider seismic actions was published by the Ministry of Housing, Utilities and New Communities in 1988, the Reinforced Concrete Code (ESEE 1988). However, the code overlooked a number of basic seismic considerations, including the influence of soil conditions and the dynamic characteristics of buildings (Fouad 1994).

Following the 1992 Cairo earthquake, the Egyptian Code for Loads and Forces issued on December 1993 (ECP-201 1993) provided an approach for determining seismic loads for different types of structures. Although this code represented an improvement in comparison with previous regulations (ESEE 1988), it still adopted significantly simplified assumptions in terms of loading considerations and design procedures. In 2004, a new code (ECP-201 2004) was issued and dealt with most of the shortcomings present in preceding standards, particularly on the earthquake loading side. This code largely follows the same 


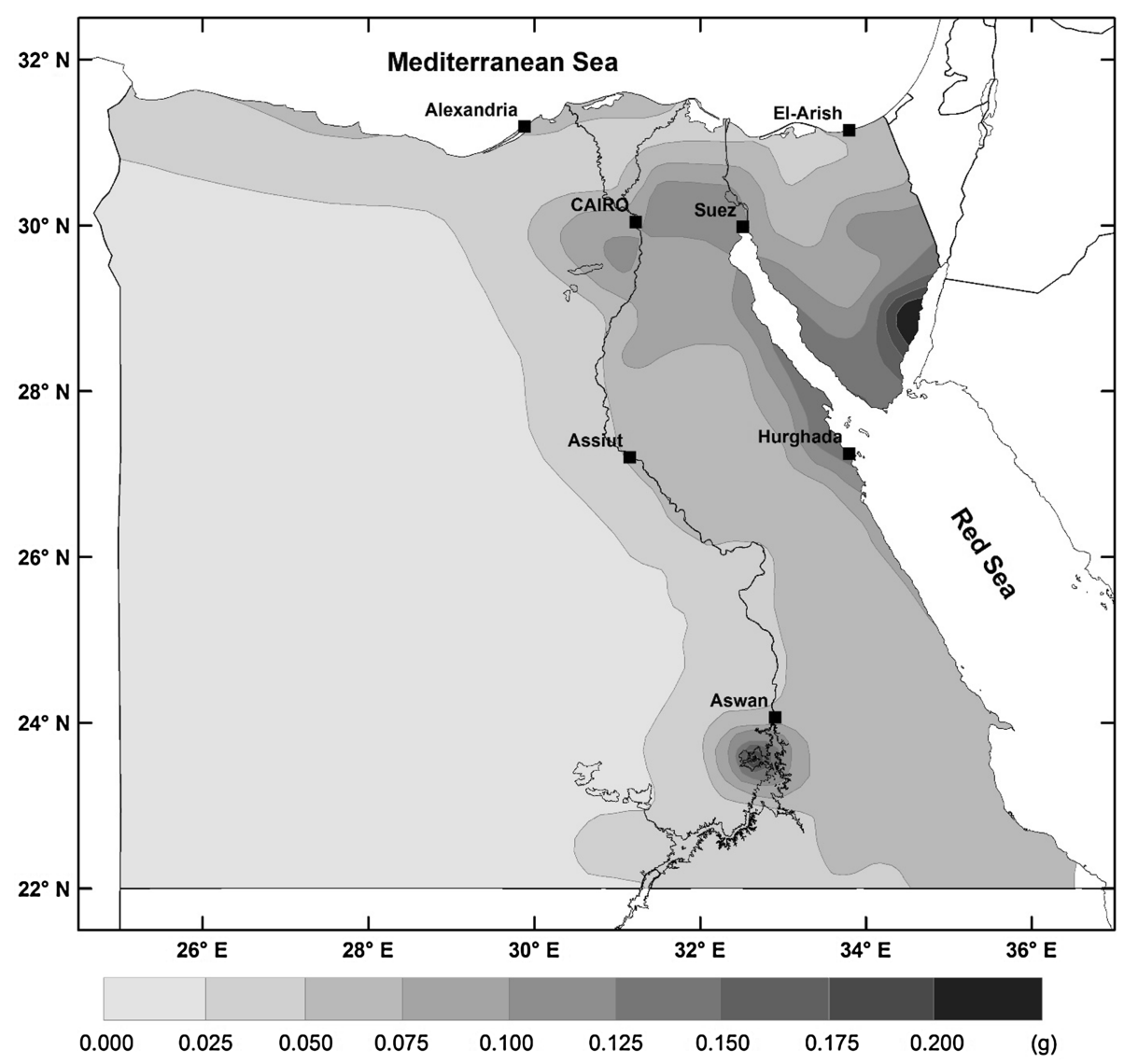

Fig. 3 Peak ground horizontal acceleration (g) for rock sites, with a $90 \%$ probability of not being exceeded in 50 years (return period of 475 years) (after El-Hadidy 2012)

framework adopted in Eurocode 8 (2004). It introduces the concept of design response spectra and codified force reduction factors for the design of structures, and includes safety verifications relevant to ultimate and serviceability limit states. Most recently, the Egyptian code gradually introduced ductility concepts and detailing procedures through its successive versions (ECP-201 2004, 2008, 2011), although these aspects of the code still need considerable improvement and development (Raheem 2013).

\subsection{Regulations of the Egyptian Society of Earthquake Engineering (ESEE 1988)}

The Regulations for Earthquake-resistant Design of Buildings in Egypt were published by the ESEE in 1988 (Sobaih 1988). A basic consideration in earthquake-resistant design is to forecast the ground motion for the site of a proposed structure. The 1988 Egyptian regulations require that buildings subjected to seismic action could be analyzed under the action of an equivalent system of static forces applied horizontally at each floor or roof level. 


\subsubsection{Total horizontal seismic force (base shear)}

The ESEE (1988) states that every building shall be designed and constructed to withstand a total horizontal seismic base shear force $V$ given by the equation.

$$
V=C_{S} \cdot W_{t}
$$

where $C_{s}$ is the seismic design coefficient and $W_{t}$ is the total weight. In all mentioned equations, we used the same abbreviations, for the different parameters, that already have been used in the quoted building codes.

The seismic design coefficient $C_{s}$ must be determined from the following formula:

$$
C_{S}=Z \cdot I \cdot S \cdot M \cdot R \cdot Q
$$

where $Z$ is the seismic zoning factor, $I$ is the importance factor, depending on the building use and occupancy, $S$ is the structural system type factor, that depends on the capacity of the structure to resist lateral forces, $M$ is the material factor, that depends on the construction material, $R$ is the risk factor, depending on the presence of flammable or toxic materials, and finally $Q$ is the construction quality factor.

\subsubsection{Seismic action}

The seismic zoning factor $Z$ is determined from the equation.

$$
Z=A \cdot C \cdot F
$$

where $A$ is the ground horizontal acceleration (Fig. 4), $C$ is the standardized response spectrum for an average damping of $5 \%$ (Fig. 5), and $F$ is the foundation soil factor.

According to the ESEE (1988) regulations, Egypt was divided into four seismic zones (Z0, Z-1, Z-2 and Z-3) according to the level of seismic activity and hazard (Fig. 4). The seismic hazard was described in terms of PGA ( $A$ factor in Eq. 3 ), which is equal to zero for areas in zone Z-0. These regions were considered of very low seismicity and shall not need any special seismic design considerations. For zones Z-1, Z-2 and Z-3, the $A$ values are equal to $0.02,0.04$ and $0.08 \mathrm{~g}$, respectively. Regions of high seismic activity (Z-3 in Fig. 4) mainly include counties that are adjacent to the Red Sea and Mediterranean Sea shores and Southern Sinai Peninsula, and around Nasser's Lake. Also, as a measure of the seismic intensity, the regulations provide seismic intensity grades for each seismic zone. For zone Z-0, the intensity grade is considered $\leq \mathrm{V}$, while for zones $\mathrm{Z}-1, \mathrm{Z}-2$, and Z-3, the intensity grades are VI, VII, and VIII, respectively.

\subsubsection{Soil conditions}

According to this regulations, the nature of the supporting soil at the construction site was classified into three subsoil types. This classification system was used to account for the influence of local ground conditions on the seismic action in terms of the foundation soil factor. $\mathrm{F}=1.0$ for rock and dense and very dense soils, $\mathrm{F}=1.3$ for compact soils, and $\mathrm{F}=1.5$ for very loose and loose soils.

\subsection{Egyptian code for the calculation of loads and forces (ECP-201 1993)}

The great losses due to the $\mathrm{M}_{\mathrm{S}}$ 5.9, October 12, 1992 Cairo earthquake, were mainly related to the fact that buildings were designed to resist only vertical loads and had 


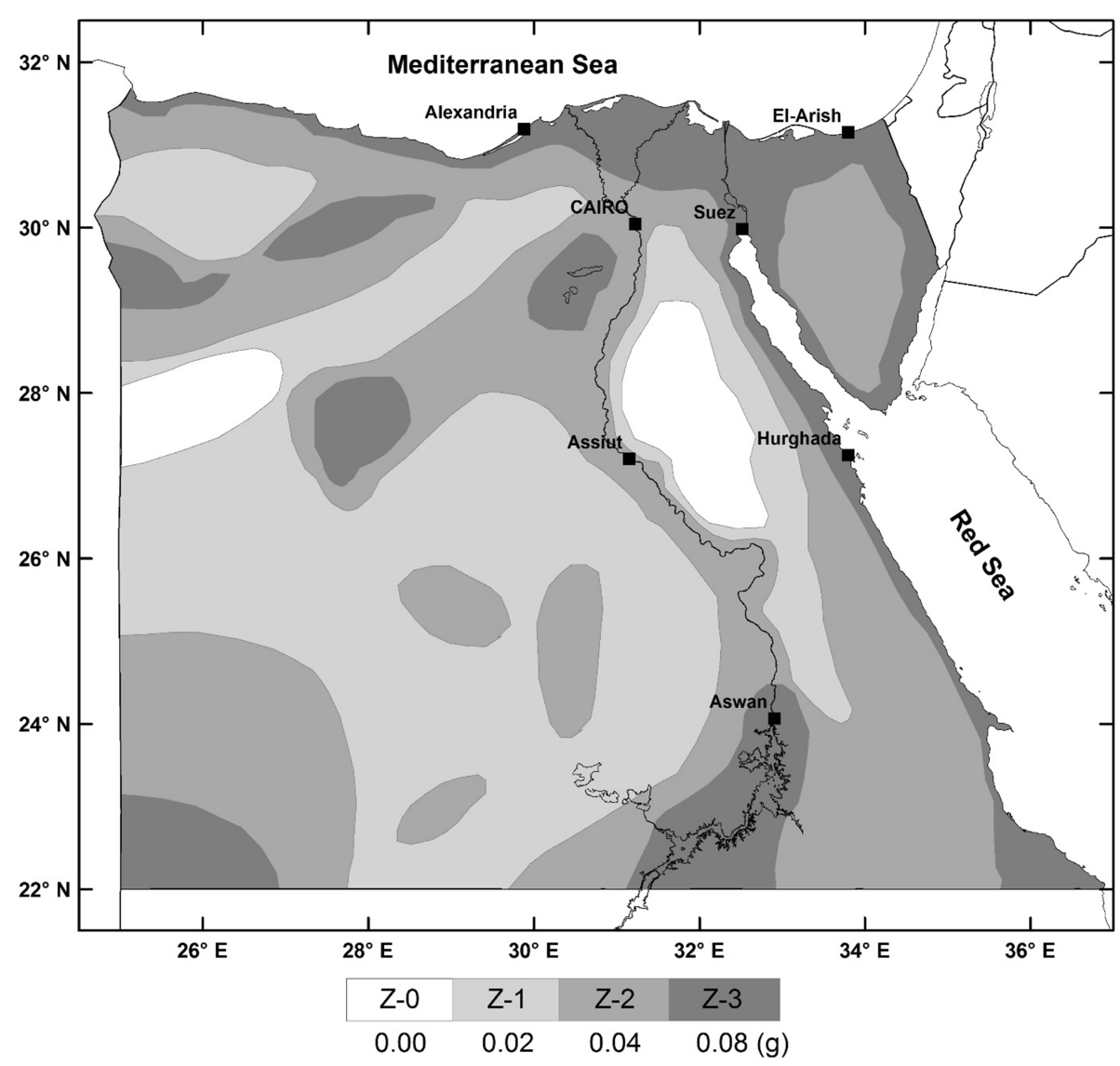

Fig. 4 Seismic activity zoning map for Egypt (redrawn after ESEE 1988)

insufficient lateral resistance. After that, it becomes a necessity to develop a new building code taking into account the shortcomings of the previous regulations. Hence, the Egyptian Code for the Calculation of Loads and Forces (ECLF) (1993) was proposed.

\subsubsection{Total horizontal seismic force (base shear)}

The ECP-201 (1993) allows to calculate the seismic design loads (lateral shear forces and torsional moments) for buildings whose height not exceed $100 \mathrm{~m}$, with height to width ratio (in the direction of the seismic force) not exceeding 5, and provided that the structural system must be uniform in plan and all through the height of the building. The structures are to be designed to resist a total horizontal seismic force $V$ acting above the foundation level in a direction parallel to each one of the two main axes of the structure separately. The seismic force must be computed according to the equation.

$$
V=Z \cdot I \cdot K \cdot C \cdot S \cdot W
$$

where $Z$ is the seismic zoning factor, $I$ is the importance factor, depending on the building use and occupancy, $K$ is the structural system coefficient, that depends on the capacity of 


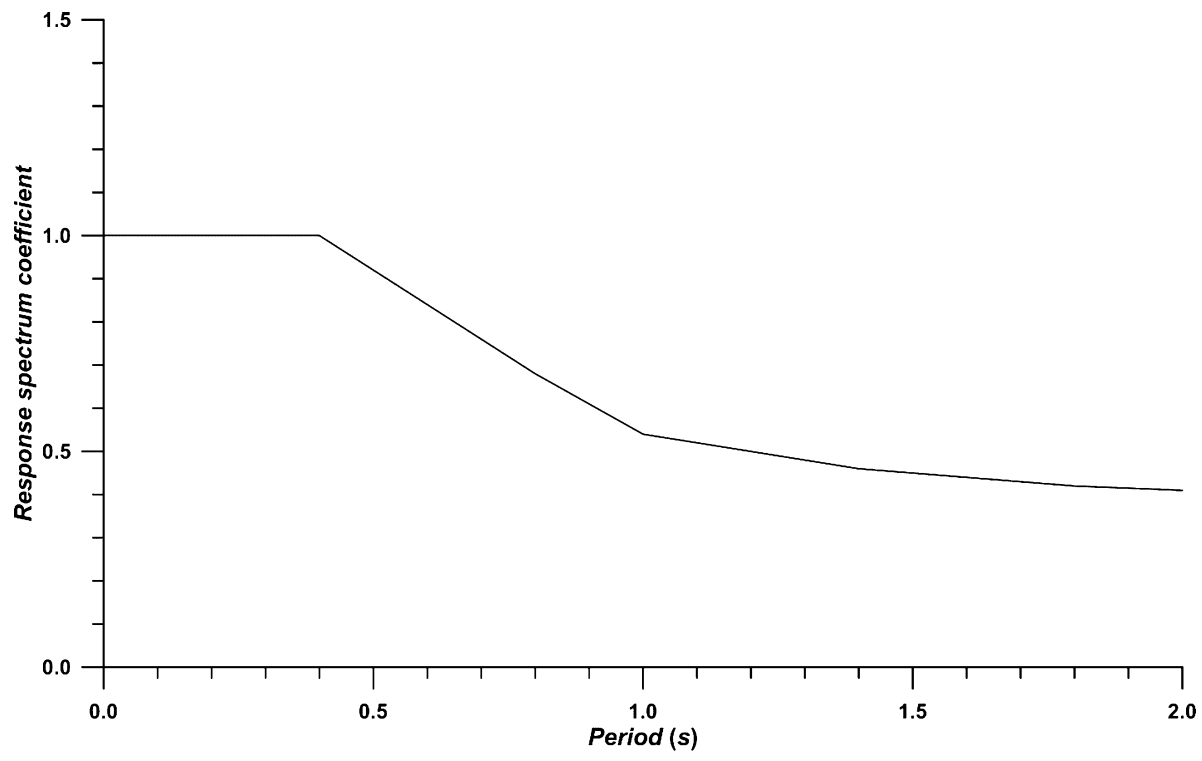

Fig. 5 Standardized response spectrum coefficient for an average damping of $5 \%$ (redrawn after Fouad 1994)

the structure to resist lateral forces, $C$ is the structural coefficient, that depends on the fundamental period of the building, $S$ is the soil coefficient, and $W$ is the total weight of the building.

The structural coefficient $C$ must be computed from the equation:

$$
C=\frac{1}{15 \sqrt{T}}
$$

where $\mathrm{T}$ is the fundamental period of vibration of the building in seconds, which depends on the total number of stories above the base of the building. $C$ shall not be greater than 0.12 .

Moreover different values for the common parameters and considered seismic hazard (seismic zoning factor), the ECP-201 (1993) code do not take into account coefficients concerning construction materials, risk factor nor construction quality factor like the previous ESEE (1988) regulations.

\subsubsection{Seismic action}

No explicit value of the design PGA was given in this code. Instead, the seismic hazard was described in terms of a seismic zoning factor, $Z$, which represents a measure of the seismic intensity of the region. The factor is dependent on the site location within the seismic activity zoning map (Fig. 6). In this code, Egypt was divided into three main zones (Z-1, Z-2 and Z-3) according to the level of seismic activity. Zone Z-1 includes all the regions which affected by low-magnitude earthquakes. This zone nearly has the same distribution as ESEE (1988) map, but it extends to more areas in the Southern Eastern Desert. Zone Z-2 includes regions of low to moderate seismic activity, which located at 


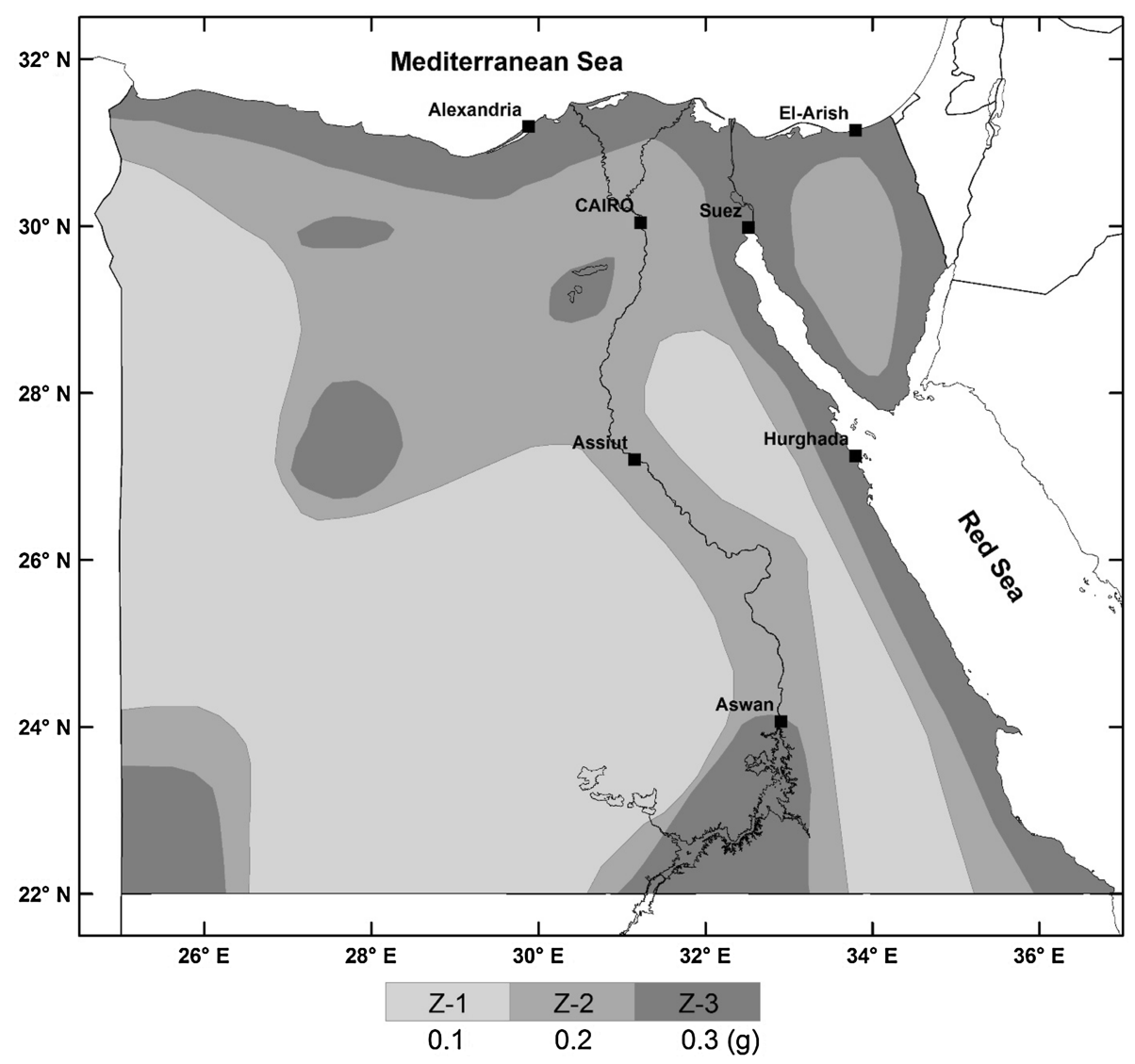

Fig. 6 Seismic activity zoning map for Egypt (redrawn after ECP-201 1993)

some parts of Sinai Peninsula, Nile Delta, Nile Valley, Eastern Desert and Western Desert. It has more extension to the southwestern direction from Cairo than in the ESEE (1988). Zone Z-3 includes areas located along the Red Sea and Mediterranean Sea coasts, and some parts from Aswan, Fayoum, and Ismailia. This last zone includes areas with moderate seismic activity. It covers the same geographical distribution as the ESEE (1988), with the exception of the area of Siwa at the Egyptian-Libyan borders. The seismic zoning factor for the three zones, in this code, is equal to $0.1,0.2$, and $0.3 \mathrm{~g}$, respectively, which completely show an increase in the acceleration values rather than the seismic zoning factor considered in the 1988 regulations.

\subsubsection{Soil conditions}

The influence of the soil on the seismic action was considered in the $S$ factor. $S=1.0$ for rock and dense or very dense soils, $S=1.15$ for medium density soils or cohesive soils, and $\mathrm{S}=1.3$ for loose or weak cohesive soils. For medium and loose soil, this factor is less than the one considered in the previous ESEE (1988) regulations ( $F$ factor in Eq. 3). 


\subsection{The Uniform Building Code (UBC-97)}

Although this is not properly an Egyptian code, we consider this regulation because it presents seismic zonation factors for many cities around the world (including Egypt) corresponding to locations of US embassies and consulates. The procedures and limitations for the design of structures shall be determined considering seismic zoning, site characteristics occupancy configuration, structural system and building height.

The UBC (1997) provided a seismic zonation map for the US, dividing it into six zones, from 0 (no seismic design was required) up to 4 , for sites near active seismic sources, with zone 2 being subdivided into two, $2 \mathrm{~A}$ and $2 \mathrm{~B}$. For each one of these zones, a seismic zone factor was provided, which corresponds to the PGA value for rock-site conditions and for a $10 \%$ probability of exceedance in 50 years. The seismic zone factors for zones 1, 2A, 2B, 3 , and 4 are $0.075,0.15,0.2,0.3$, and $0.4 \mathrm{~g}$, respectively. Three Egyptian cities are included in the zone 2A. They are Alexandria, Cairo and Port Said.

\subsection{Egyptian codes for the calculation of loads and forces (ECP-201 2004, 2008, 2011)}

After the occurrence of the $\mathrm{M}_{\mathrm{S}}$ 5.9, October 12, 1992 Cairo earthquake, the scientists and engineers gave great attention to revising code for seismic loads, and it was modified several times. Since October 1992, a set of Egyptian regulations have been released to prevent building collapse and/or control major damage of structural elements. Furthermore, the Egyptian Government takes into account generating several periodical building codes which consider more up-to-date aspects than the previous ones. Three codes were elaborated since 2004 until now. They are the Egyptian Codes for the Calculation of Loads and Forces (ECLF) 2004, 2008 and 2011. Concerning the seismic action in the three codes, there is a great similarity between them, thus we will discuss them together.

\subsubsection{Seismic action}

In these codes, Egypt was divided into five seismic zones (Fig. 7), depending on the seismic hazard. By definition, the hazard within each zone is assumed to be constant. The seismic hazard is described in terms of a single parameter, $a_{g}$, which represents the design PGA for rock. For zones 1, 2, 3 and 4, the $a_{g}$ values are $0.10,0.125,0.15$ and $0.20 \mathrm{~g}$, respectively. Zone 5 was subdivided into two sub-zones, $5 \mathrm{a}$ and $5 \mathrm{~b}$, with $a_{g}$ values of 0.25 and $0.30 \mathrm{~g}$, respectively.

These codes provide the seismic zoning map, which depicts the seismic hazard in terms of PGA with a $10 \%$ probability of exceedance in 50 years, corresponding to a return period of 475 years. The map was based on the work done by Riad et al. (2000), discussed before, and considered in the GSHAP (1999). In addition, the code was supplied with a complementary table that shall be used in companion with the seismic zoning map to determine what is the seismic zone in which are included the main cities and regions of Egypt.

\subsubsection{Soil conditions}

According to the ECP-201 (2004, 2008) codes, the nature of the supporting soil at the construction site shall be classified into four subsoil types, from A to D. In ECP-201 


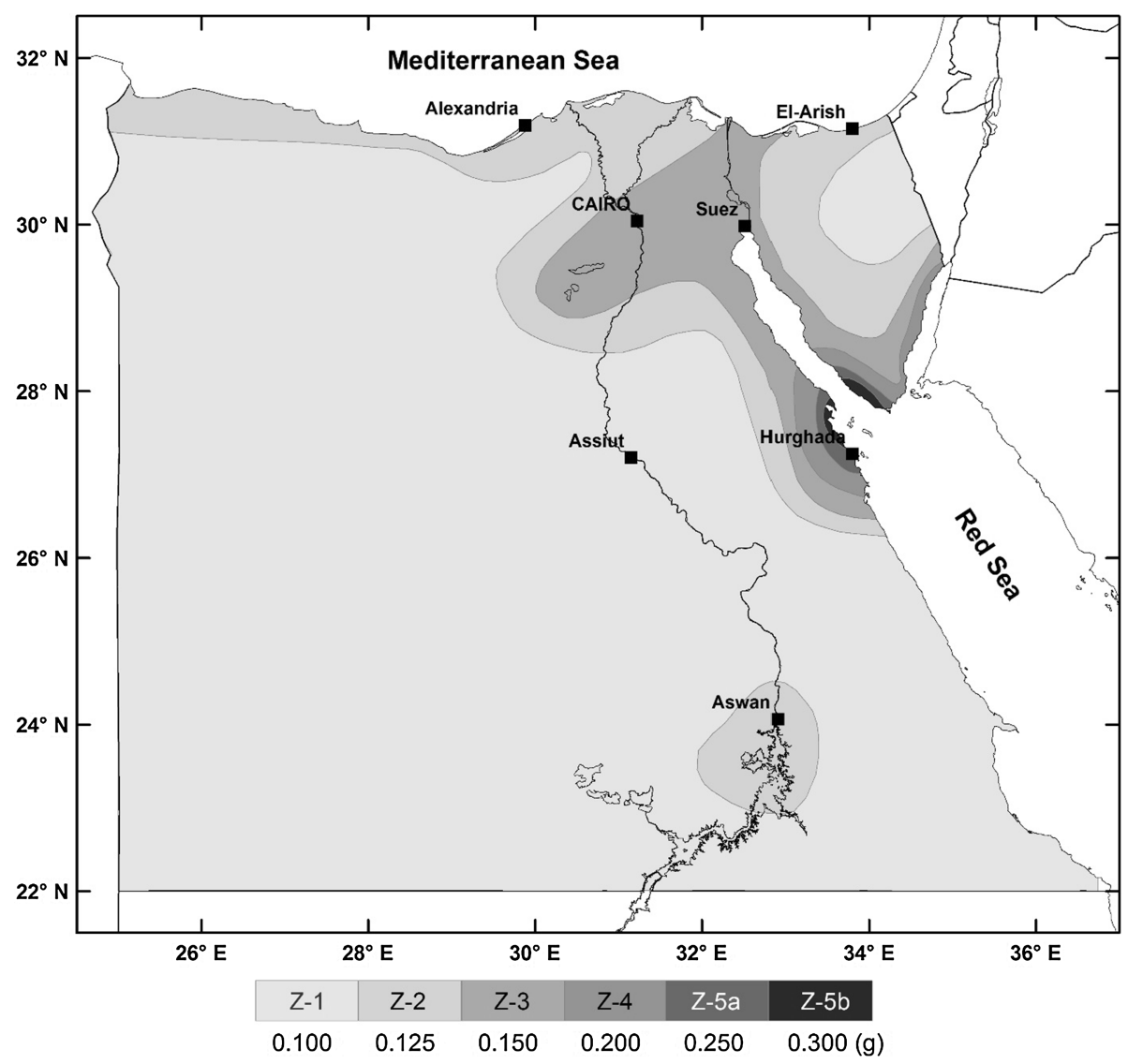

Fig. 7 Seismic activity zoning map for Egypt (redrawn after ECP-201 2004, 2008, 2011 and Riad et al. 2000)

(2011), an additional soil type was also included that is named as E (Table 4). The classification is based upon the value of the average shear wave velocity. For sites with ground conditions not matching any of the four subsoil classes defined by the code, special studies for the definition of the seismic action are required.

\subsubsection{Basic representation of the seismic action}

Within the scope of ECP-201 $(2004,2008,2011)$ codes, the earthquake motion at a given point was represented by an elastic response spectra. The code provides two types of spectrum shapes, Type 1 and Type 2 (Fig. 8). The Type 2 response spectrum must be used for coastal areas lying on the Mediterranean Sea up to distance of $40 \mathrm{~km}$ away from the coast, while Type 1 spectrum must be applied for all other regions. The selection of the appropriate acceleration values for a specific site must be determined according to the seismic zoning map and its companion table attached to the code itself.

The seismic action was represented by a horizontal elastic response spectrum, in the same way as Eurocode 8 (2004), defined by the following expression (Fig. 8): 
Table 4 Classification of subsoil conditions according to ECP-201 (2004, 2008, 2011)

\begin{tabular}{lll}
\hline $\begin{array}{l}\text { Soil } \\
\text { Class }\end{array}$ & Description & $\begin{array}{l}\text { Shear wave } \\
\text { velocity }\end{array}$ \\
\hline
\end{tabular}

ECP-201 (2004, 2008, 2011) codes

A Rock layer (weak to medium weathering) extends to at least $15 \mathrm{~m}$ thick, and $>800 \mathrm{~m} / \mathrm{s}$ probably including at most $3 \mathrm{~m}$ of weaker material at the surface

B Cohesionless soil (gravel, sand) — very dense soil, or cohesive soil (silt, clay)— $360-800 \mathrm{~m} / \mathrm{s}$ very stiff soil. Layers extend to at least $15 \mathrm{~m}$ thick

C Cohesionless soil (gravel, sand) — dense or medium-dense soil, or cohesive soil 180-360 m/s (silt, clay)—stiff to medium-stiff soil. Layers extend to at least $15 \mathrm{~m}$ thick

D Cohesionless soil (gravel, sand)—loose soil, or cohesive soil (silt, clay)—soft or $\quad<180 \mathrm{~m} / \mathrm{s}$ collapsing soil. Layers extend to at least $15 \mathrm{~m}$ thick

Only considered in ECP-201 (2011) code

E Surface layer composed from alluvium deposits overlain more compatible material

$$
S_{e}(T)=\left\{\begin{array}{cr}
a_{g} \cdot S \cdot\left[1+\frac{T}{T_{B}} \cdot(2.5 \eta-1.0)\right] \gamma_{1} & 0 \leq T \leq T_{B} \\
2.5 a_{g} \cdot S \cdot \eta \gamma_{1} & T_{B} \leq T \leq T_{C} \\
2.5 a_{g} \cdot S \cdot \eta \cdot\left[\frac{T_{C}}{T}\right] \gamma_{1} & T_{C} \leq T \leq T_{D} \\
2.5 a_{g} \cdot S \cdot \eta \cdot\left[\frac{T_{C} \cdot T_{D}}{T^{2}}\right] \gamma_{1} & T_{D} \leq T \leq 4 \mathrm{~s}
\end{array}\right.
$$

where $T$ is the vibration period of a linear single-degree-of-freedom system, $a_{g}$ is the design ground acceleration for the reference return period (475 years for a building with importance factor $\gamma_{1}$ equal to 1.0), $T_{B}$ and $T_{C}$ are the lower and upper limits of the constant spectral acceleration (SA) branch, $T_{D}$ is the period value defining the beginning of the constant displacement response change of the spectrum, $\eta$ is the design damping correction factor for the horizontal elastic response spectrum, where a reference value of $\eta=1$ corresponds to a normal $5 \%$ viscous damping ratio, $S$ is the soil factor, and $\gamma_{1}$ is the importance factor of the building [considered only in the ECP-201 $(2008,2011)$ codes]. $S, T_{B}, T_{C}$, and $T_{D}$ are only function of the ground type category (A to D) assigned to the site (Table 5).

\subsection{Review and remarks among the different codes}

One important and major difference between the ECP-201 (1993) and the subsequent codes is the fact of the adoption of a response spectrum. El-Arab (2011) proclaim that the newest provisions, ECP-201 (2004, 2008, 2011) have a similar formulation, with the exception of the importance factor both in response spectrum $\left(\gamma_{1}\right)$ and in the base shear equation $(I)$, which yields final identical base shear.

Table 6 is an attempt to show the similarities and differences between the Egyptian building codes from a point of view of the seismic action values. It displays the considered seismic action for a 2-stories residential building in rock site in some of the most populated cities, some of them were located within the highest seismic hazard area in Egypt. We noticed that the seismic zoning factor $(A)$ for some cities (e.g., Cairo and Assiut) in the ECP-201 (1993) is approximately ten times those values $(Z)$ considered in the ESEE (1988). This do not means that the resultant seismic action is also ten times, because there 


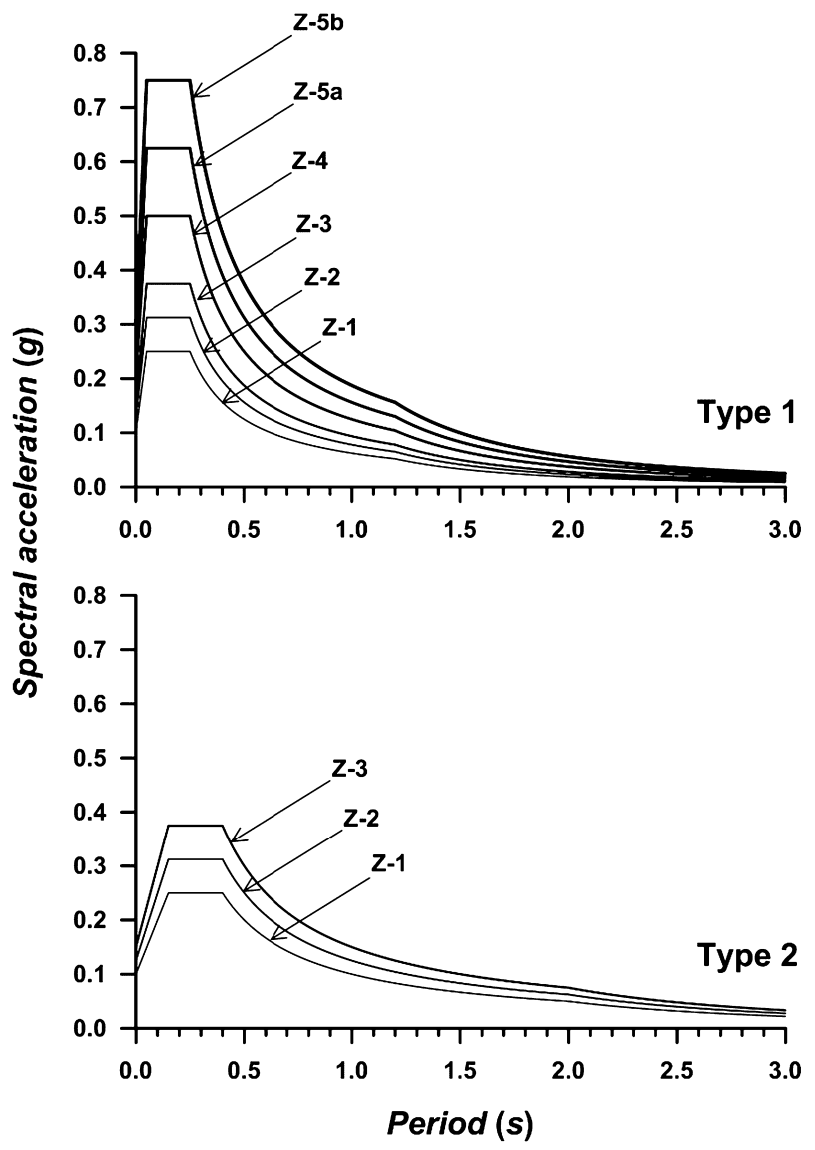

Fig. 8 Type-1 elastic response spectra for all considered seismic zones (from 1 to 5) and Type-2 spectra for the zones (from 1 to 3 ) located along the Mediterranean Sea coast. Spectra plotted for rock and $5 \%$ damping

is another factor that in turn decreasing the final result. This factor is the structural coefficient factor ( $C$ in Eqs. 3, 4) which behaves in the contrary, and reduces ten times in the ECP-201 (1993) than in previous regulations. Moreover, there is a significant increase (e.g., 19 times for Cairo city and 12 times for Assiut city) in the final seismic action values when comparing the most recent ECP-201 (2004, 2008, 2011) codes with the previous regulations (ESEE 1988; ECP-201 1993).

All in all, these major changes among the successive Egyptian building codes, will in turn affect not only the values of the seismic action in each code, but will affect the building design itself. El-Arab (2011) noticed that the base shear value obtained from ECP201 (2004, 2008) is greater than the values obtained using ECP-201 (1993).

\section{Summary and conclusions}

The current study aimed at reviewing and evaluating the previous seismic hazard assessment studies and their representation in the Egyptian building codes. We find that, many seismic hazard studies were done in the last decades upon the whole Egyptian territory as 
Table 5 Parameters for the different soil classes for both Type- 1 and Type-2 elastic response spectra in ECP-201 (2004, 2008, 2011)

\begin{tabular}{|c|c|c|c|c|c|c|c|c|}
\hline \multirow{2}{*}{$\begin{array}{l}\text { ECP-201 }(2004,2008) \text { codes } \\
\text { Soil class }\end{array}$} & \multicolumn{4}{|c|}{ Type 1 spectrum } & \multicolumn{4}{|c|}{ Type 2 spectrum } \\
\hline & $S$ & $T_{B}$ & $T_{C}$ & $T_{D}$ & $S$ & $T_{B}$ & $T_{C}$ & $T_{D}$ \\
\hline A (rock) & 1.00 & 0.05 & 0.25 & 1.20 & 1.00 & 0.15 & 0.40 & 2.00 \\
\hline B (stiff soil) & 1.35 & 0.05 & 0.25 & 1.20 & 1.20 & 0.15 & 0.50 & 2.00 \\
\hline C (soft soil) & 1.50 & 0.10 & 0.25 & 1.20 & 1.25 & 0.20 & 0.60 & 2.00 \\
\hline D (very soft soil) & 1.80 & 0.10 & 0.30 & 1.20 & 1.35 & 0.20 & 0.80 & 2.00 \\
\hline \multicolumn{9}{|l|}{ ECP-201 (2011) code } \\
\hline E (alluvium deposits) & 1.60 & 0.05 & 0.25 & 1.20 & 1.40 & 0.15 & 0.50 & 2.00 \\
\hline
\end{tabular}

Table 6 Seismic action for rock, for a typical 2-stories residential building $(\mathrm{T}=0.2 \mathrm{~s})$

\begin{tabular}{llll}
\hline City/seismic action & ESEE (1988) & ECP-201 (1993) & $\begin{array}{l}\text { ECP-201 (2004, } \\
\text { 2008, 2011) } \\
\end{array}$ \\
& $\begin{array}{l}\text { A.C.F } \\
\text { Eq. (3) }\end{array}$ & $\begin{array}{l}Z \cdot C \cdot S \\
\text { Eq. }(4)\end{array}$ & $\begin{array}{l}S_{e}(T) \\
\text { Eq. }(6)\end{array}$ \\
\hline Cairo & $0.02 \cdot 1.00 \cdot 1.00=0.02 \mathrm{~g}$ & $0.20 \cdot 0.12 \cdot 1.00=0.02 \mathrm{~g}$ & Type $10.38 \mathrm{~g}$ \\
Alexandria & $0.08 \cdot 1.00 \cdot 1.00=0.08 \mathrm{~g}$ & $0.30 \cdot 0.12 \cdot 1.00=0.04 \mathrm{~g}$ & Type $20.33 \mathrm{~g}$ \\
Suez & $0.08 \cdot 1.00 \cdot 1.00=0.08 \mathrm{~g}$ & $0.30 \cdot 0.12 \cdot 1.00=0.04 \mathrm{~g}$ & Type $10.38 \mathrm{~g}$ \\
Assiut & $0.02 \cdot 1.00 \cdot 1.00=0.02 \mathrm{~g}$ & $0.20 \cdot 0.12 \cdot 1.00=0.02 \mathrm{~g}$ & Type $10.25 \mathrm{~g}$ \\
Hurghada & $0.08 \cdot 1.00 \cdot 1.00=0.08 \mathrm{~g}$ & $0.30 \cdot 0.12 \cdot 1.00=0.04 \mathrm{~g}$ & Type $10.63 \mathrm{~g}$ \\
Aswan & $0.08 \cdot 1.00 \cdot 1.00=0.08 \mathrm{~g}$ & $0.30 \cdot 0.12 \cdot 1.00=0.04 \mathrm{~g}$ & Type $10.31 \mathrm{~g}$ \\
\hline
\end{tabular}

well as for specific regions. We compared and described these studies in terms of the study region, the analysis approach, the used earthquake catalogue, the seismic source model, the considered attenuation relationship, the software code and the representation of the results (Table 2). In addition, we compared the obtained values between these studies by choosing six cities in Egypt and studying PGA values or the PGA range in which it is included each city in each study (Table 3). Moreover, a detailed review for the seismic action in the successive Egyptian building codes was outlined, showing the seismic action for specific cities considered in the different codes (Table 6).

Several seismic hazard assessments using different approaches have been done in Egypt. Each one of these assessments had used different earthquake catalogues, seismic source models, and attenuation relationships. Hence, it is expected to get different results among them. All the more, from Table 6 it is clear that successive building codes gives different seismic action values for each city. Other question is the fact that the current building code (ECP-201 2011), which based on Riad et al. (2000) study, do not give a certain PGA value for each city in Egypt, and it just divides the whole territory of Egypt into six broad zones, assigning to each zone only one seismic action value. Moreover, the current building code uses two types of an elastic response spectra, one of them is for the sites which are located along the Mediterranean coast and the other is for all sites in Egypt. We are encouraging to use only one elastic response spectrum, including some parameters in order to consider the potential Eastern Mediterranean subduction zone effects.

In conclusion, we are recommending the following. The establishment of a scientific committee which its main goal could be establishing a new building code that represents 
the seismic action for each city correctly and precisely. This committee should include geologists, seismologists and engineers. Geologists should be concerned to assess the current knowledge on active faults throughout Egypt. Seismologists should be established a new assessment of the seismic hazard for the Egyptian territory. This assessment should be based on the compilation of an updated earthquake catalogue, and a consensual seismic source model based on all available geological, geophysical and seismological data. Moreover, seismologists should be interested in establishing an attenuation relationship for Egypt if there are enough acceleration data to do it. If not, they have the choice to employ either a theoretical stochastic model or apply some worldwide widely used attenuation models in a "consensus decision-making". After that, engineers must start in designing and implementing a new building code which could represent the most updated and consensually knowledge on the seismic action for each city.

Acknowledgments We would like to thank the two anonymous reviewers for their valuable comments and suggestions. This research work is supported by the Egyptian Ministry of the Higher Education (Cultural Affairs and Missions Sector, Cairo) and the Spanish Seismic Hazard and Active Tectonics research group. In addition, appreciation is necessary goes to Prof. Amin Saleh Aly, Faculty of Engineering, Ain Shams University, who provides us some critical information about the Egyptian building codes.

\section{References}

Abdel Rahman M, Tealeb A, Mohamed A, Deif A, Abou Elenean K, El-Hadidy MS (2008) Seismotectonic zones at Sinai and its surrounding. In: 1st Arab conference on astronomy and geophysics, Helwan, Egypt, 20-22 Oct 2008

Abdel-Fattah AK, Hussein HM, El-Hady S (2006) Another look at the 1993 and 1995 Gulf of Aqaba earthquakes from the analysis of teleseismic waveforms. Acta Geophys 54:260-279

Abou Elenean K (1993) Seismotectonics of the Mediterranean region north of Egypt and Libya. Master Dissertation, Mansoura University, Egypt

Abou Elenean K (1997) Seismotectonics of Egypt in relation to the Mediterranean and Red Sea tectonics. Ph.D. Dissertation, Ain Shams University, Egypt

Abou Elenean K (2007) Focal mechanism of small and moderate size earthquakes recorded by the Egyptian National Seismic Network (ENSN), Egypt. NRIAG J Astron Geophys 6:119-153

Abou Elenean K (2010) Seismotectonics Studies of El-Dabaa and its surroundings. Unpublished Report

Abou Elenean KM, Hussein HM, Abu El-Ata AS, Ibrahim EM (2000) Seismological aspects of the Cairo earthquake, 12th October 1992. Ann Geofis 43:485-504

Abou Elenean KM, Mohamed AME, Hussein HM (2010) Source parameters and ground motion of the SuezCairo shear zone earthquakes, Eastern Desert, Egypt. Nat Hazards 52:431-451

Abrahamson NA, Silva WJ (1997) Empirical response spectral attenuation relations for shallow crustal earthquakes. Seism Res Lett 68:94-127

Albert RNH (1986) Seismicity and earthquake hazard at the proposed site for a nuclear power plant in the El-Dabaa area, north western desert, Egypt. Acta Geophys Pol 34:263-281

Albert RNH (1987) Seismicity and earthquake hazard at the proposed site for a nuclear power plant in the Anshas area, Nile delta, Egypt. Acta Geophys Pol 35:343-363

Ambraseys NN (1961) On the seismicity of the south-west Asia (date from a XV century Arabic manuscript), Revue pour L'étude calamités. Genkve 37:18-30

Ambraseys NN (1978) Middle East reappraisal of seismicity. Q J Eng Geol Hydrogeol 11:19-32

Ambraseys NN (1983) A note on historical seismicity. Bull Seismol Soc Am 73:1917-1920

Ambraseys NN (2001) Far-field effects of Eastern Mediterranean earthquakes in Lower Egypt. J Seismol 5:263-268

Ambraseys NN, Adams RD (1993) Seismicity of the Cyprus region. Tera Nova 5:85-94

Ambraseys NN, Melville CP, Adams RD (1994) The seismicity of Egypt, Arabia and Red Sea. Cambridge University Press, Cambridge

Ambraseys NN, Simpson KA, Bommer JJ (1996) The prediction of horizontal response spectra in Europe. Earthq Eng Struct D 25:371-400 
Atkinson GM, Boor DM (1995) New ground-motion relations for eastern North America. Bull Seismol Soc Am 85:17-30

Atkinson GM, Boor DM (1997) Some comparisons between recent ground-motion relations. Seism Res Lett 68: $24-40$

Badawy A (1998) Earthquake hazard analysis in northern Egypt. Acta Geodaetica et Geophysica Hungarica 33:341-357

Badawy A (1999) Historical seismicity of Egypt. Acta Geodaetica et Geophysica Hungarica 34:119-135

Badawy A (2005) Seismicity of Egypt. Seism Res Lett 76:149-160

Badawy A, Al-Gabry M, Girgis M (2010) Historical seismicity of Egypt, a study for previous catalogues producing revised weighted catalogue. In: The second Arab conference for astronomy and geophysics, Helwan, Egypt

Ben-Avraham Z, Nur A, Cello G (1987) Active transcurrent fault system along the north African passive margin. Tectonophysics 141:249-260

Bender B, Perkins D (1987) SEISRISK III, a computer program for seismic hazard estimation. US Geol Surv Bull 1772:48

Ben-Menahem A (1979) Earthquake catalogue for the Middle East (92 B.C.-1980 A.D.). Bollettino di Geofisica Teorica ed Applicata 21:245-310

Boore DM, Joyner WB, Fumal TE (1997) Equations for estimating horizontal response spectra and peak acceleration from western North American earthquakes: a Summary of recent work. Seism Res Lett 68:128-153

Campbell KW (1981) A ground motion model for the Central United States based on near-source acceleration data. In: Proceeding of conference on earthquakes and earthquake engineering: The Eastern US., vol 1. Knoxville, Tennessee, pp 213-232

Campbell KW, Bozorgnia Y (2003) Updated near-source ground motion (attenuation) relations for the horizontal and vertical components of peak ground acceleration and acceleration response spectra. Bull Seismol Soc Am 93:314-331

Campbell KW, Bozorgnia Y (2008) NGA ground motion model for the geometric mean horizontal component of PGA, PGV, PGD and $5 \%$ damped linear elastic response spectra for periods ranging from 0.01 to 10 s. Earthq Spectra 24:139-171

Cochran JR (1983) A model for the development of the Red Sea. AAPG bull 67:41-69

Crouse CB (1991) Ground-motion attenuation equations for earthquakes on the Cascadia subduction zone. Earthq Spectra 7:201-236

Deif A, Abou Elenean K, El-Hadidy M, Tealeb A, Mohamed A (2009) Probabilistic seismic hazard maps for Sinai Peninsula, Egypt. J Geophys Eng 6:288-297

Deif A, Hamed H, Igrahim HA, Abou Elenean K, El-Amin EM (2011) Seismic hazard assessment in Aswan, Egypt. J Geophys Eng 8:531-548

ECP-Egyptian Code of Practice-201 (1993) Egyptian code for calculating loads and forces. National Research Center for Housing and Building, Ministry of Housing, Utilities and Urban Planning, Cairo

ECP-Egyptian Code of Practice-201 (2004) Egyptian code of practice no. 201 for calculating loads and forces in structural work and masonry. National Research Center for Housing and Building, Ministry of Housing, Utilities and Urban Planning, Cairo

ECP-Egyptian Code of Practice-201 (2008) Egyptian code of practice no. 201 for calculating loads and forces in structural work and masonry. National Research Center for Housing and Building, Ministry of Housing, Utilities and Urban Planning, Cairo

ECP-Egyptian Code of Practice-201 (2011) Egyptian code of practice no. 201 for calculating loads and forces in structural work and masonry. National Research Center for Housing and Building, Ministry of Housing, Utilities and Urban Planning, Cairo

El-Adham KA, El-Hemamy ST (2006) Modelling of seismic hazard for El-Dabaa area, Egypt. B EngGeol Environ 65:273-279

El-Arab IE (2011) Seismic analysis of existing school buildings using different Egyptian seismic provisions. In: The Twelfth East Asia-Pacific conference on structural engineering and construction. Procedia Engineering 14:1906-1912

El-Gamal AW, Amer M, Adalier K, Abdul-Fadl A (1993) Engineering aspect of the October 12, 1992 Egyptian earthquake. Technical report NCEER 91-7000B, National Center for Earthquake Engineering Research, State University of New at Buffalo, USA

El-Hadidy M (2012) Seismotectonics and seismic hazard studies in and around Egypt. Ph D. Dissertation, Ain Shams University, Egypt

El-Hefnawy M, Deif A, El-Hemamy ST, Gomaa NM (2006) Probablistic assessment of earthquake hazard in Sinai in relation to the seismicity in the eastern Mediterranean region. B Eng Geol Environ 65:309-319 
El-Sayed A, Wahlström R (1996) Distribution of the energy release, b-values and seismic hazard in Egypt. Nat Hazards 13:133-150

El-Sayed A, Wahlström R, Kulhánek O (1994) Seismic hazard of Egypt. Nat Hazards 10:247-259

El-Sayed A, Vaccari V, Panza GF (2001) Deterministic seismic hazard in Egypt. Geophys J Int 144:555-567

Engdahl ER, Van Der Hilstand R, Buland R (1998) Global teleseismic earthquake relocation with improved travel times and procedures for depth determination. Bull Seismol Soc Am 88:722-743

ENSN_Egyptian National Seismic Network Bulletins (1998-2010) earthquakes in and around Egypt. National Research Institute of Astronomy and Geophysics (NRIAG), Cairo, Egypt

ESEE_-Egyptian Society for Earthquake Engineering (1988) Regulations for earthquake resistant design of buildings in Egypt

Eurocode 8 (2004) Design of structures for earthquake resistance. Part 1: general rules, seismic actions and rules for buildings. EN1998-1. European Committee for Standardization, Brussel

Fat-Helbary RE (1994) Assessment of seismic hazard and risk in Aswan area, Egypt. Ph D. Dissertation, Tokyo University, Japan

Fat-Helbary RE (1999) Investigation and assessment of seismic hazard in Egypt. Unpublished Report Submitted to MAPFRE, Spain

Fat-Helbary RE (2003) Probablistic analysis of potential ground motion levels at the principal cities in Upper Egypt. J Appl Geophys 2:279-286

Fat-Helbary RE and Ohta Y (1996) Assessment of Seismic Hazard in Aswan Area, Egypt. In: 11th World conference on earthquake engineering. Paper No. 136 Published by Elsevier Science Ltd

Fat-Helbary RE, Tealeb AA (2002) A study of seismicity and earthquake hazard at the proposed Kalabsha dam site, Aswan, Egypt. Nat Hazards 25:117-133

Fat-Helbary RE, El Khashab HM, Dojcinovski D, El Faragawy KO, Abdel-Motaal AM (2008) Seismicity and seismic hazard analysis in and around the proposed Tushka new city site, south Egypt. Acta Geodynamica et Geomaterialia 5:389-398

Fouad FH (1994) Egypt. In: Paz M (ed) International Handbook of Earthquake Engineering, pp 195-204

GSHAP-Global Seismic Hazard Assessment Project (1999). http://www.seismo.ethz.ch/static/GSHAP/

Hamouda AZ (2011a) Recent evaluation of the assessment seismic hazards for Nuweiba, Gulf of Aqaba. Arab J Geosci 4:775-783

Hamouda AZ (2011b) Assessment of seismic hazards for Hurghada, Red Sea, Egypt. Nat Hazards 59:465-479

Hassoup A, Tealab A (2000) Attenuation of intensity in the northern part of Egypt associated with the May 28, 1998 Mediterranean earthquake. Acta Geophys Pol 48:79-92

ISC-International Seismological Centre (2011) On-line Bulletin, International Seismological Centre, Thatcham, United Kingdom. http://www.isc.ac.uk

Joyner WB, Boore DM (1981) Peak horizontal acceleration and velocity from strong motion records including records from 1979 Imperial Valley, California. Bull Seismol Soc Am 71:2011-2038

Kebeasy RM (1990) Seismicity. In: Said R (ed) The geology of Egypt. A.A. Balkerma, Rotterdam, pp 51-59

Kebeasy RM, Maamoun M, Albert RNH (1981) Earthquake activity and earthquake risk around the Alexandria area in Egypt. Acta Geophys Pol 29:37-48

Maamoun M (1979) Macroseismic observation of principal earthquakes in Egypt. Bulletin of Helwan Institute of Astronomy and Geophysics No. 183

Maamoun M, El-Khashab HM (1978) Seismic studies of the Shedwan (Red Sea) earthquake. Bull Helwan Inst Astron Geophys 171:22-46

Maamoun M, Allam A, Megahed A (1984) Seismicity of Egypt. Bulletin of Helwan Institute of Astronomy and Geophysics, 109-160

Makropoulos KC, Burton PW (1981) A catalogue of seismicity in Greece and adjacent areas. Geophys J Roy Astron Soc 65:741-762

Makropoulos KC, Burton PW (1985) A Fortran program to evaluate hazard parameters using Gumbel's theory of extreme value statistics. National Environment Research Council, Institute of Geological Sciences, Edinburgh

McGuire RK (1976) FORTRAN computer programs for seismic risk analysis, United States Geological Survey. Open-File Report No. 76-67

McGuire RK (1994) EQRISK Fortran computer program for seismic risk analysis. United States Geological Survey. Open-File Report

McKenzie D (1972) Active tectonics in the Mediterranean region. Geophys J Roy Astron Soc 30:109-185

Meshref W (1990) Tectonic framework. In: Said R. (ed) The geology of Egypt. A.A. Balkerma, Rotterdam, Netherlands, pp 113-155

Mohamed AA, El-Hadidy M, Deif A, Abou Elenean K (2012) Seismic hazard studies in Egypt. NRIAG J Astron Geophys 1:119-140 
Neev D (1975) Tectonic evolution of the Middle East and the Levantine basin (easternmost Mediterranean). Geology 3:683-686

Ordaz M, Aguilar M, Arboleda J (2007) CRISIS 2007: program for computing seismic hazard written by Derechos Reservados. (C) Institute of Engineering, UNAM, Mexico

Papaioannou ChA, Papazachos BC (2000) Time-independent and time-dependent seismic hazard in Greece based on seismogenic sources. Bull Seismol Soc Am 90:22-33

Papazachos BC (1990) Seismicity of the Aegean and surrounding area. Tectonophysics 178:287-308

Papazachos BC, Papaioannou ChA (1993) Long-term earthquake prediction in the Aegean area based on a time and magnitude predictable model. Pure appl Geophys 140:595-612

Papazachos B, Papazachos C (1997) On Greek earthquakes. Ziti Publications, Thessaloniki, p 340

Papazachos BC, Papazachou C (2003) The earthquakes of Greece. Ziti Publications, Thessaloniki, p 289

PDE-Preliminary Determination of Epicentre: USGS National Earthquake Information Center (NEIC). http://earthquake.usgs.gov/earthquakes/

Petrovski J, Mihailov V, Jordanovski LI (1983) Trans-european north-south motorway project (TEM), V. I seismic hazard maps, United Nations Development Programme-Economic Comission for Europe

Poirier J, Taher M (1980) Historical seismicity in the near and Middle East, North Africa and Spain from Arabic documents (VIIth-XVIIth century). Bull Seismol Soc Am 70:2185-2201

Pollastro RM (2003) Total petroleum systems of the Paleozoic and Jurassic, Greater Ghawar Uplift and adjoining provinces of Central Saudi Arabia and Northern Arabian-Persian Gulf. US. Geological Survey Bulletin 2202-H

Raheem SEA (2013) Evaluation of Egyptian code provisions for seismic design of moment-resisting-frame multi-story buildings. Int J Adv Struct Eng 5:1-18

Riad S, Meyers H (1985) Earthquake catalogue for the Middle East countries (1900-1983). National Geophysical Data Centre, World Data Centre A for Solid Earth Geophysics. Rep. SE-40. National Oceanic and Atmospheric Administartion (NOAA), US Department of Commerce, Boulder, Colorado, USA

Riad S, Ghalib M, El-Difrawy MA, Gamal M (2000) Probabilistic Seismic Hazard Assessment in Egypt. Ann Geol Surv Egypt 23:851-881

Salamon A, Hofstetter A, Garfunkel Z, Ron H (2003) Seismotectonics of the Sinai subplate-the eastern Mediterranean region. Geophys J Int 155:149-173

Sawires R, Ibrahim HA, Fat-Helbary RE, Peláez JA (2014) A seismological database for Egypt including updated seismic and focal mechanism catalogues. In: 8th Spanish-Portuguese assembly of geodesy and geophysics, Évora, Portugal, 29-31 January 2014

Sawires R, Peláez J, Fat-Helbary RE, Ibrahim HA, García-Hernández MT (2015) An updated seismic source model for Egypt. In: Moustafa A (ed). Earthquake engineering-from engineering seismology to optimal seismic design of engineering structures. InTech. ISBN: 978-953-51-4116-7

Shapira A (1994) Seismological Bulletin of Israel, 1900-1994

Shapira A and Shamir G (1994) Seismicity parameters of seismogenic zones in and around Israel. The Institute of Petroleum Research and Geophysics. Report No. Z1/567/79 (109)

Sobaih M (1988) Regulations for earthquake-resistant design of buildings in Egypt. Egyptian Soceity for Earthquake Engineering (ESEE), Cairo, p 340

Sobaih ME, Kebeasy RM, Ahmed KA (1992) Development of seismic hazard maps for Egypt. Int J Earthq Eng 2:33-58

UBC-Uniform Building Code (1997) Volume 2: structural engineering design provisions. International Conference of Building Officials (ICBO), Whittier

WCC-Woodward-Clyde Consultants (1985) Earthquake activity and stability evaluation for the Aswan high dam. Unpublished report. High and Aswan Dam Authority, Ministry of Irrigation, Egypt

Youngs RR, Chiou SJ, Silva WJ, Humphery JR (1997) Strong ground motion attenuation relationships for subduction zone earthquakes. Seism Res Lett 68:58-73

Zhao JX, Zhang J, Asano A, Ohno Y, Oouchi T, Takahashi T, Ogawa H, Irikura K, Thio HK, Somerville OG, Fukushima Y, Fukushima Y (2006) Attenuation relations of strong ground motion in Japan using site classification based on predominant period. Bull Seismol Soc Am 96:898-913

Ziegler MA (2001) Late Permian to Holocene paleofacies evolution of the Arabian Plate and its hydrocarbon occurrences. GeoArabia 6:445-504 